\title{
Cross-boundary Conservation Attributes of Farmland and Woodland Owners in the Greenbrier River Valley Landscape of Southeastern West Virginia
}

Valerie Grant

Follow this and additional works at: https://researchrepository.wvu.edu/etd

\section{Recommended Citation}

Grant, Valerie, "Cross-boundary Conservation Attributes of Farmland and Woodland Owners in the Greenbrier River Valley Landscape of Southeastern West Virginia" (2015). Graduate Theses, Dissertations, and Problem Reports. 5703.

https://researchrepository.wvu.edu/etd/5703

This Thesis is protected by copyright and/or related rights. It has been brought to you by the The Research Repository @ WVU with permission from the rights-holder(s). You are free to use this Thesis in any way that is permitted by the copyright and related rights legislation that applies to your use. For other uses you must obtain permission from the rights-holder(s) directly, unless additional rights are indicated by a Creative Commons license in the record and/ or on the work itself. This Thesis has been accepted for inclusion in WVU Graduate Theses, Dissertations, and Problem Reports collection by an authorized administrator of The Research Repository @ WVU. For more information, please contact researchrepository@mail.wvu.edu. 


\title{
Cross-boundary Conservation Attributes of Farmland and Woodland Owners in the Greenbrier River Valley Landscape of Southeastern West Virginia
}

\author{
Valerie Grant
}

\author{
Thesis submitted to \\ Davis College of Agriculture, Natural Resources and Design \\ at West Virginia University \\ in partial fulfillment of the requirements for the degree of \\ Master of Science in Forestry
}

David W. McGill, Ph.D.; Chair
Kathryn Arano Gazal, Ph.D.
Harry N. Boone, Jr., Ph.D.
School of Natural Resources

Morgantown, West Virginia

2015

Key words: private forest owners, cross-boundary cooperation, sense of place, conservation ethic, economic dependence, farmlands, woodlands

(C) 2015 Valerie Grant 


\section{ABSTRACT \\ Cross-boundary Conservation Attributes of Farmland and Woodland Owners in the Greenbrier River Valley Landscape of Southeastern West Virginia.}

Valerie Grant

The Greenbrier River watershed features some of the most productive agriculture and timberlands, critical habitat, and extensive recreational opportunities in the central Appalachian Mountains. Cross-boundary conservation projects could address landscape scale issues such as parallelization and fragmentation in the agricultural, forest, and recreationally productive rural area in southeastern West Virginia. A survey of farmland and woodland owners explored relationships between landowner attributes, land management activities, sense of place, and willingness to participate in cross-boundary conservation efforts. Logistic regression analysis revealed two significant relationships between landowner attributes when considering neighboring properties while making management decisions and interest in conservation easements. These two attributes, contact with an agriculture professional or registered forester and conservation ethic (the affinity to and responsibility for land) could increase interest in cross-boundary conservation programs. Conservation ethic also had a negative relationship with interest in allowing leased access to properties for recreation or hunting, possibly because of perceived loss of privacy, identity, or control. Two main implications for reaching out to landowners and increasing participation in cross-boundary programs are: 1 . Create opportunities for landowners to make contact with an agriculture or forestry professional, and 2. Design cross-boundary programs which mirror landowners existing practices, such as leasing. 


\section{Acknowledgements}

I dedicate this thesis to the ones who are working the land in the valleys and small towns, whether they are in a West Virginia holler or a ridge overlooking the foggy Pacific Ocean in northern California. Where we live and where we come from can become a part of us -for that I am truly thankful.

Thank you to my family, friends, and mentors for their support. Thank you to my committee and Dave McGill Ph.D., my advisor, for the opportunity. 


\section{Table of Contents}

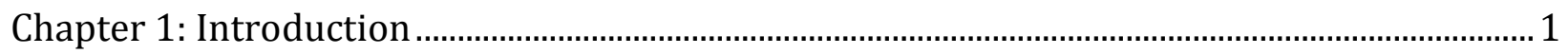

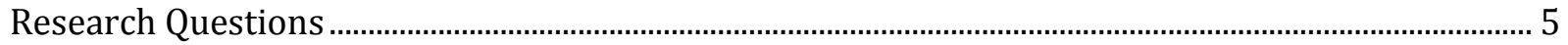

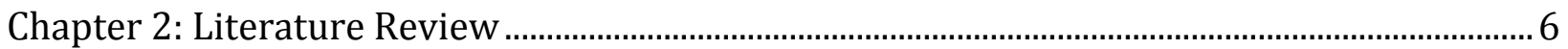

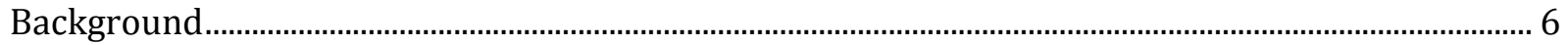

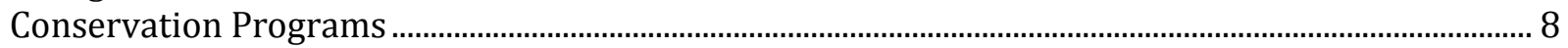

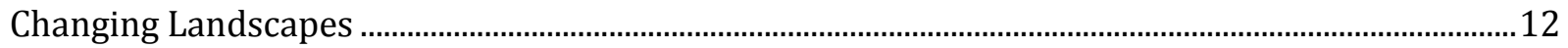

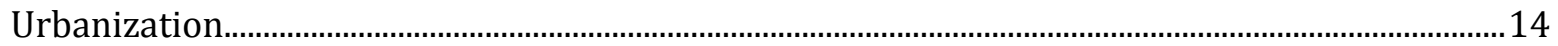

Understanding and managing trends in land ownership..................................................................15

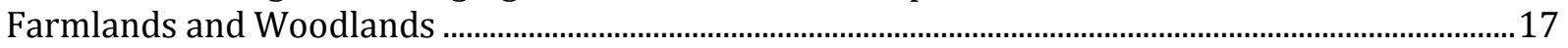

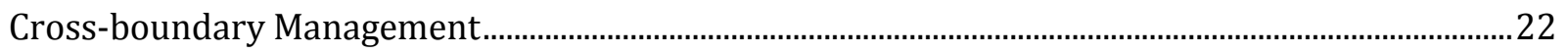

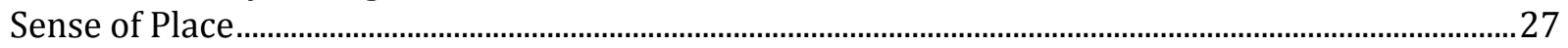

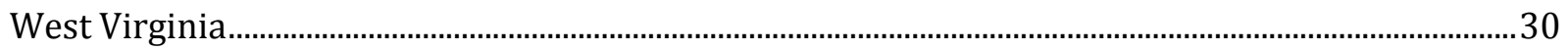

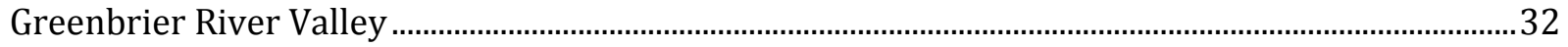

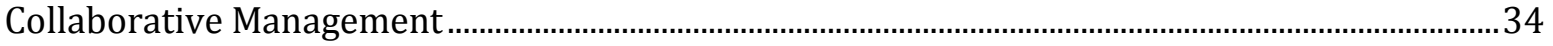

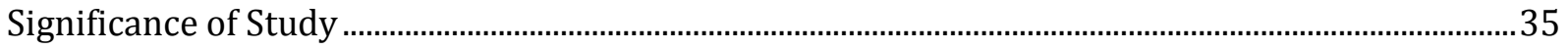

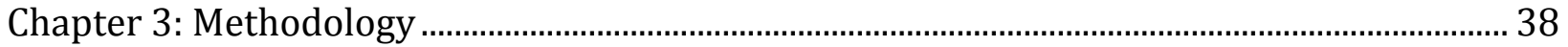

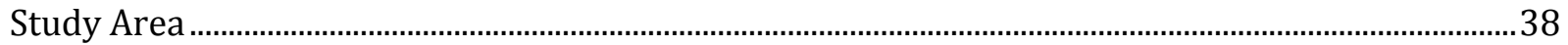

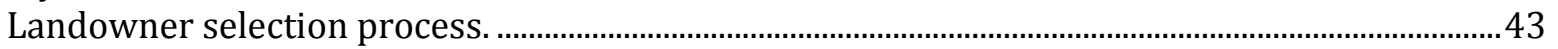

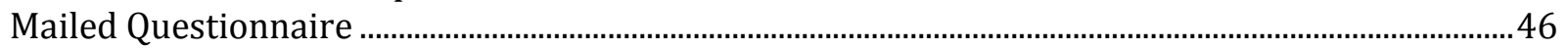

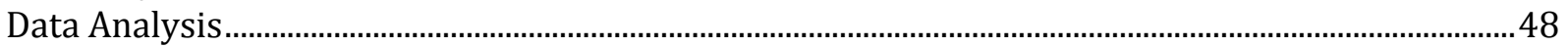

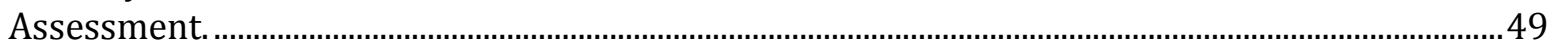

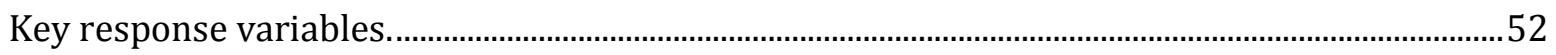

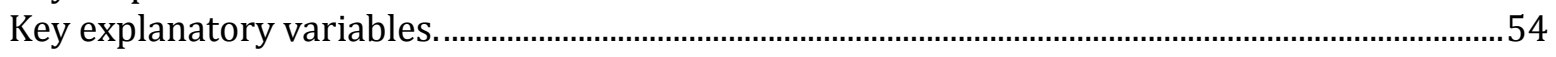

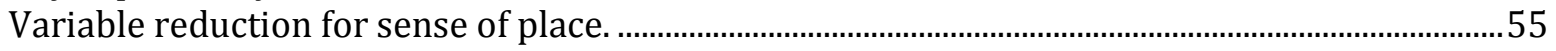

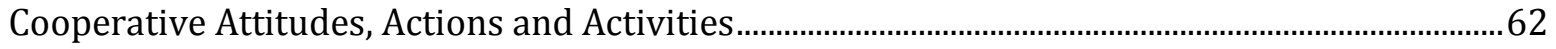

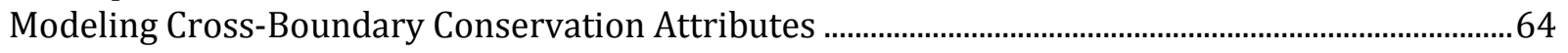

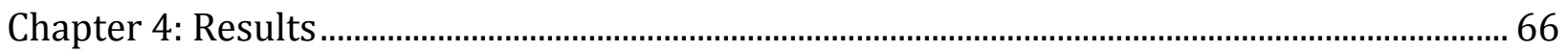

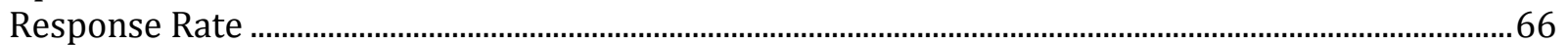

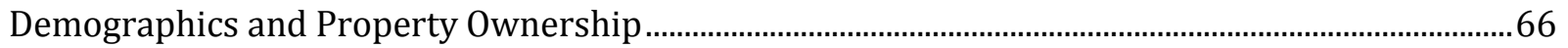

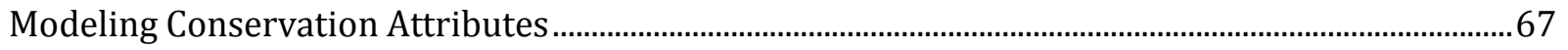

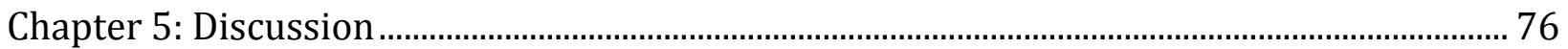

Implications for Managing Farmlands and Woodlands …………………………………………………....78

Implications for Outreach and Education .................................................................................................... 82

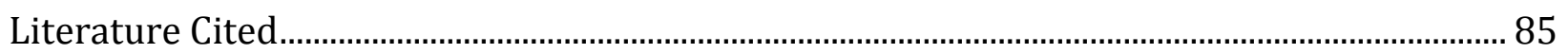




\section{List of Figures}

Figure 1: West Virginia Non-Industrial Private Forestland 2014 State Assessment............... 30 Figure 2 - Greenbrier River Valley Landscape-map featuring agriculture and forestland cover in the study area............................................................................................................. 39 Figure 3: Parallel analysis for sense of place showing eigenvalues of components 1-16 from Greenbrier River Valley farmland and woodland owner questionnaire data and corresponding eigenvalues at the 95th percentile of values generated from random populations 


\section{List of Tables}

Table 1: Survey items related to sense of place and factor structure for PCA with Varimax rotation related to sense of place.

Table 2: Description of Response and Explanatory Variables to use in logistic models........ 63

Table 3: Results of logistic regression model assessment for the attitude of considering the ecological health of neighboring or nearby properties when making decisions concerning their land (ECOHEALTH).

Table 4: Results of logistic regression model assessment for the action of neighbors or owners of nearby properties have speaking to respondents about their management decisions (MGTDEC)

Table 5: Results of logistic regression model assessment for interest in talking with neighbors about managing wildlife habitat together in the future (HABITAT).

Table 6: Results of logistic regression model assessment for interest in working with neighbors to write a conservation easement agreement to protect more than one ownership from development (CONEASE)...

Table 7: Results of logistic regression model assessment for Interest in asking neighbors to join a group to lease hunting and recreation access to their shared properties in the future (ACCESS)

Table 8: "Best" modes assessment of strength of covariate relationships with dichotomous response variables (ECOHEALTH and MGTDEC).

Table 9: "Best" modes assessment of strength of covariate relationships with dichotomous response variables (HABITAT, ACCESS, and CONEASE). 


\section{Chapter 1: Introduction}

The conservation of natural resources in the United States has far reaching benefits to landowners and society. Benefits that accrue to society include public goods such as clean air, clean water, aesthetics, and open space (Goldman, 2006; MEA, 2006). The importance of these resources are exemplified in federal policy that has recently changed to reflect a "landscape level" focus where all working lands-specifically farmlands and woodlandsare important in the effort to maintain healthy ecosystems (Vilsack, 2009).

Promoting healthy landscape-scale ecosystems is a complex effort, made up of many institutions, agencies, organizations, and stakeholders with goals that aim to increase the productivity of and reduce the threats to working lands (Pirot et al., 2000; Colyer, 1998). European agricultural environmental schemes and an array of United States conservation programs encourage private landowners to reduce soil erosion, protect water quality, enhance wildlife habitat and preserve areas of scenic, cultural and historical value, all while promoting the capability of these lands to produce food and fiber (Baylis et al., 2008; Jordan \& Warner, 2010).

Both human and environmental forces shape landscapes (Goldman, 2006; MEA, 2005). Demands for residential, urban, and industrial development threaten the quality and extent of working landscapes (Egan \& Luloff, 2000; Dwyer \& Childs, 2004). Many threats to these landscapes transcend boundaries beyond a landowner's parcel level, including water pollution, wildfires, and invasive species (Zedler, 2003; Fischer \& Charnley, 2012). 
The Natural Resources Conservation Service (NRCS), USDA Forest Service (USDA FS) and other federal programs promote agriculture and forestry conservation efforts at a landscape level (Knight, 2013). Landscape management transcends boundaries. A crossboundary approach is more appropriate for addressing threats, such as the spread of invasive plants, than a site-by-site, uncoordinated approach (Higgins et al., 2007).

Working landscape management, and sustainable forestry on mixed ownership landscapes of private and public lands requires people to work together on some level in crossboundary efforts (Rickenbach \& Reed, 2002). Rickenbach et al. (2011) defines crossboundary cooperation as "voluntary behavior whereby one or more landowners account for the plan and practices on adjacent and/or nearby properties." While challenging barriers exist, in general previous work indicates broad potential interest from the "average" non-industrial private forest owner (NIPF) in cooperating at scales beyond their own fence lines (Finley et al., 2006).

Recent research has begun to explore attributes associated with landowner willingness to engage in cross-boundary conservation efforts (Finley et al., 2006). The search for attributes that might indicate a landowner's willingness to engage in a collaborative, landscape-scale project plays an important role in federal, state, and local agencies efforts in marketing conservation programs to landowners. 
Place attachment, satisfaction, and meanings each contribute to a person's willingness to engage in behaviors that maintain or improve valued attributes of a setting (Stedman, 2002). These personal attributes can be described as "sense of place", a collection of symbolic meanings, attachment, and satisfaction with a spatial setting held by an individual or group (Williams \& Stewart, 1998). Sense of place could act as a mediating factor in facilitating cross-boundary collaboration efforts. Cheng (2003) found that common experiences, understanding of the biophysical landscape, and group identity may increase a group of landowners' ability to engage in dialogue, produce shared understanding and meaning, reduce conflicts and improve collaborative relationships. Another factor that could foster participation and collaboration is representing landowners' opinions, tenure patterns and interests, inclusive of the individuals and groups of landowners that are stakeholders (Rickenbach et al., 2004). These opinions, patterns and interests could be reflected in policy, project development and educational programs when targeting landscape-scale management results.

Cross-boundary efforts and other programs are aimed at farmers and other landholders to meet one primary challenge -the majority of these lands, particularly in the eastern United States are privately owned (Gorte, 2012). These private ownerships have different levels of access to financial and educational resources and have different preferences for management activities on their properties (Koontz, 2001; Kuhns et al., 1998; Kittredge, 2004). Landowners have diverse ownership objectives and emotional attachment to the land (Rickenbach \& Reed, 2002; Egan, 1997; Fischer \& Bliss, 2008; Jackson, 1980). 
Many programs, outreach efforts and research studies are structured around the needs and wants of the average private forest owner, which might not be the most effective or inclusive strategy (Finley et al., 2006). Non-Industrial private forest owners, and programs directed at them, cannot be treated as a one homogenous community (Salmon et al., 2006). Attempting to gain a better understanding of the effect of these private ownerships on landscape-scale management, should include understanding the land use practices of new owners, as well as how the historical, cultural, and physiographic characteristics of local landscapes as they merge with private ownerships management preferences (Gosnell et al., 2006).

There is a need for continued study, reflection and representation of the privately-owned landscape since access to private land is essential for conservation of biological diversity (Rickenbach et al., 2004). Methods should integrate conservation with land used for farms, forests and urban dwellings rather than separating them (Norton, 2000).

In areas where working lands such as agriculture are being lost to development, pressures on other working lands such as forests increase. In West Virginia, much of the best farmland lies in valley bottoms, creating conflicts between working lands and areas targeted for development (WVDOF, 2010). The Greenbrier River is one such area facing potential growth and development. The river stretches across four counties in southeastern West Virginia and is valued for its ecological diversity, forest and agriculture industry, recreation, and culture (EIS, 1986). 
Given the valuable nature of Greenbrier River region for conservation purposes, a study was developed to assess potential interest in cross-boundary conservation projects and to understand conservation issues facing landowners. In addition to other determinants of landowner behavior established in earlier work (e.g., Joshi \& Arano, 2008; Starr \& McConnell, 2014; Kay \& Nelson, 2007), two land use types of ownership (agriculture and woodland) and sense of place were explored as potential predictors of differing outlooks on conservation activities and willingness to engage in cross-boundary conservation efforts. This study is intended to provide understanding of the conservation attributes of landowners for purposes related to conservation program outreach and promotion in the Greenbrier River landscape of southeastern West Virginia.

\section{Research Questions}

This study explores relationships between landowner attributes, land management activities, and willingness to participate in cross-boundary conservation efforts. Of primary concern are landowners' conservation attributes and their future conservation directions for their properties. The underlying purpose of this study is to improve outreach efforts related to natural resources management of private lands in West Virginia.

Specifically the research question is:

How are conservation attributes and willingness to participate in cross-boundary conservation of landowners in the Greenbrier River landscape in southeastern West Virginia related to landownership and property characteristics, personal sense of place, and demographic attributes? 


\section{Chapter 2: Literature Review}

\section{Background}

The United States covers 2.3 billion acres. Private landowners own 60 percent (1.4 billion acres), 38 percent is public land controlled by federal, state and local governments and the Bureau of Indian Affairs manage the remaining lands (Nickerson et al., 2011). Nearly all cropland is privately owned and over half of grassland pasture, range and forestland is in private ownership (Hoppe \& Weibe, 2000; USDA, 2000). These ownerships have a unique combination of resources, management control, and objectives (Butler \& Leatherberry, 2004).

Private landowners are diverse and this diversity presents challenges to accepted sustainable management practices (Kuhns, 1998; Butler, 2008; Matson et al., 1997; Kvarda, 2004; Hoppe et al., 1999). This diversity of ownership objectives leads to a mosaic of properties with differing management priorities and creates management challenges in the broader landscape (Rickenbach et al., 2004). Numerous typologies and market segmentation strategies have attempted to understand differences among landowners and suggest that understanding landowner types can help conservation agencies effectively promote conservation efforts on private lands (Hodgdon \& Tyrrell, 2003). 
Landowners' management and conservation decisions are influenced by factors such as size of land holding, land tenure, residence, personal values, economic considerations, past behavior, future plans, advice or information received, as well as various sociodemographic factors (Brook et al., 2003). Previous research has focused on understanding of private landowner characteristics, attitudes, beliefs and actions (Butler \& Leatherberry, 2004; Burton, 2004; Hodgdon \& Tyrrell, 2003), as well as behavioral and identity attributes related to landowner property ownership (Karppinen, 1998; Allison, 1996; Conner et al., 1998; Williams et al., 1994). Research has explored associations of landowner attributes with important conservation behaviors (Gootee et al., 2010) and various studies have focused specifically on motivations for adopting conservation practices and management priority characteristics (Ryan et al., 2003; Lambert et al., 2005).

Existing literature on forest conservation programs has focused on three areas of research: investigating family forest owners' awareness and perceptions of existing programs; examining the impact of existing programs on sustainable forest management and land conservation; and identifying challenges of and potential for improving existing programs (Ma et al., 2010). A small population of family forest owners, often referred to as 'model owners', are known to be generally committed to active management and likely to adopt various programs that promote forest or land stewardship (Kittredge, 2004; Langer, 2008). 
These research efforts aimed to clarify understanding of landowners so industry, educators, or policy makers could better understand or serve them. For example, Joshi and Arano (2009) examined four categories of forest management activities in West Virginia and found they were associated with a suite of landowner, property ownership, and management priority characteristics. These categories aimed to be helpful in directing policy instruments to motivate landowners in active forest management and further the understanding of private forest landowners. Joshi and Arano (2009) suggested future research should look specifically at how engaging in one forest management activity affects the decision of the landowners to engage in other activities.

\section{Conservation Programs}

Federal policies from the United States Department of Agriculture (USDA) Natural Resources Conservation Service (NRCS), USDA Farm Service Agency, and USDA Forest Service provide funding to states to implement various conservation programs on private lands (Batie, 2001). These agencies work collaboratively on projects that range from crop tree management to conservation easements and programs that conserve or protect land from development (Scherr \& McNeely, 2008). The general aim of programs such as the Environmental Quality Incentives Program (EQIP), Forest Stewardship Program, and Conservation Reserve Program (CRP) is to maintain or enhance the productivity of farmland and woodland ecosystems so they will continue to provide public benefits (Alberini \& Segerson, 2002). 
The Conservation Reserve Program (CRP) through the United States Department of Agriculture (USDA) was started in 1985 to protect highly erodible soils on agricultural lands (Dunn et al., 1993). Through 10-15 year contracts CRP uses positive economic incentives to encourage operators, and landowners to convert cropland and other environmentally sensitive lands to a conservation use (Johnson \& Clark, 2001). This program has also provided significant environmental benefit such as reducing fragmentation on lands (Dunn et al., 1993).

The NRCS provides financial and technical assistance to help manage natural resources in a sustainable manner with conservation grants, easements and partnership programs such as Environmental Quality Incentive Program (EQIP). These programs encourage innovation in conservation projects and provide payments for landowners for a range of projects like creating wildlife habitat or improving air quality (USDA NRCS, 2015). 
The Regional Conservation Partnership Program (RCP) and the 2014 Farm Bill emphasizes a focus on building effective partnerships and obtaining landscape level results for natural resource concerns. For example the Chesapeake Bay Watershed Initiative (CBWI), which includes 7 states (Delaware, Maryland, New York, Pennsylvania, Virginia, West Virginia, District of Columbia) collaborates with farmers, ranchers, and woodland owners to target efforts to reduce nitrogen, phosphorus and sediment loads coming from private lands. Through the (CBWI) landowners voluntarily install conservation practices across the landscape (hundreds of thousands of acres annually) to help support rural economies, protect wildlife habitat, and improve water quality in the Chesapeake Bay Watershed. This and other programs focus on existing locally led efforts and partnerships to improve outcomes through landscape conservation initiatives (USDA NRCS, 2015).

The Forest Stewardship Program, promulgated through the 1990 Farm Bill, provides support to private landowners through technical assistance in managing their forestlands through assistance in developing forest management plans for their properties (USDA Forestry Title, n.d.; Jennings \& McGill, 2005). The Farmland Protection Act (2003) led to the creation of West Virginia Farmland Protection Boards which aim to protect agricultural land and woodland as open-space (West Virginia Farmland Protection, 2003, act section, 4) by guiding acquisitions of property, advising and promoting the protection of farmland (Craig, n.d). 
In Europe, agri-environmental schemes (AES) are part of the Common Agricultural Policy and pay farmers for managing their land to conserve both nature values, such as wildlife habitat within agricultural landscapes and fields, and food production on the same land (de Snoo et al., 2013). These programs help to enhance the resiliency of these private lands against the many threats that transcend boundaries. In terms of the AES, de Snoo et al. (2013) lists 4 types of mechanisms for encouraging conservation: 1) economic and market based, 2) economic and based on public contract, 3) legal/legislative approach, and 4) social moral. The fourth component of de Snoo's list, the social aspect of natural resource management, is often overlooked.

In attempts to address social issues in natural resource management, outreach and education efforts assist landowners in making informed decisions that protect and conserve natural resources and ecosystem services (Kittredge, 2004; Butler, 2007). Investments in conservation, restoration, and sustainable ecosystem use are accepted as avenues to provide substantial ecological and economic and social benefits (De Groot et al., 2010). 
Outreach education agencies and organizations are used to promote natural resources conservation practices on private lands (Sagor et al., 2014). Outreach and education efforts assist landowners in making decisions that protect and conserve natural resources and ecosystem services (Ma et al., 2012). In the United States, this agency has traditionally been the Cooperative Extension Service (Graham, 1994). Non-profit organizations, grassroots groups, and land trusts also provide education about land stewardship and land management to both public and private landowners (Stern, 2006)

\section{Changing Landscapes}

Forest ownership is changing drastically in some regions and conversion to urban and developed land use are projected to cause a net loss of over 18 million acres of forestland by 2040 (Erikson, 2002). Land continues to be divided into smaller parcels in a process called parcelization, which can alter the connectivity of land cover and result in fragmentation (the conversion of one land type to another) (Mehmood \& Zhang, 2001). Parcelization and fragmentation not only threaten wildlife corridors, ecological diversity of forests, and scenic beauty, but also the livelihood of those who depend on these forest and agricultural resources (Marcouiller et al., 2002).

Landscapes are not only places for working, but places for living and places for visitingthis should be considered as an important force driving landscape changes as decisions about forest may not be related to the production value of the landscape (Primdahl, 1999). The ability to provide food and fiber for our growing population relies on high diversity and productivity of agricultural and forested ecosystems (Pimentel et al., 1992). 
In the past, researchers often understood farmland landscape change caused by-product of agriculture production on the landscape; however, the landscape effects of non-production values on the agriculture landscape is now drawing more attention (Busck, 2002). People are purchasing rural properties for open-space and rural life amenity values rather than traditional production values (Egan \& Luloff, 2000). Properties may be converted for industrial use, developed into vacation homes or otherwise modified to adapt to the landowner's interests and values.

Some landowners feel that enjoying and protecting their land is more valuable than to "produce" from it (Rickenbach \& Kittredge, 2009). The new landowners may make decisions for their property as a 'living place' (in the sense of a place to live in) rather than as a place of production (Primdahl, 1999). This considers that property is a social process, of multiple narratives where people view property in many ways (Freyfogle, 1998). This differs from the classical Lockean approach that defines ownership as 'natural' and is based on labor values and private individual rights (Bromley, 1991).

Even in seemingly homogeneous communities, landowners can have different definitions of private property (Yung \& Balsky, 2006). There is diversity within the production values of a landowner; even where the farmer and the owner are the same person, the 'owner' may take very different types of decisions than the 'producer' does (Primdahl, 1999). They may feel inclined to protect some areas more than others, particularly in their view shed. 


\section{Urbanization.}

The development of prime farmland (and all working farm lands) represents a threat to sustainable forestry as well as agriculture production (Sampson \& DeCoster, 2000). This may not be due to forests being cleared for farming to replace the lost farmland or from having forests adjacent to developed farmland cleared for development, although that may occur in some places (Alverson, 1994). The threat is most likely from the "urbanization" of formerly rural areas, speeding a shift from a rural-oriented culture toward one that is more urban-oriented (Wilkinson, 1991). The movement of these new owners, individuals and families with urban backgrounds to areas where they differ from their rural neighbors is often called ex-urbanization (Egan \& Luloff, 2009.)

A "rural" area encompasses all population, housing, and territory not included within an urban area (2010 Census). The 2010 Census identifies a delineation of geographic areas (both individual urban areas and the rural areas of the nation). A territory is considered an urban area if the area identified encompasses at least 2,500 people, at least 1,500 of which reside outside institutional group quarters. There are two types of urban areas: Urbanized Areas (UAs) of 50,000 or more people and Urban Clusters (UCs) of at least 2,500 and less than 50,000 people (Census, 2010). 
Trends of exurban growth across the United States and conversion and abandonment of agriculture lands in the eastern United States have important implications affecting the functioning of ecological systems (Brown, 2005; Wear \& Bolstad, 1998). Two other major trends influence change on the landscape-the division of large industrial holdings into smaller parcels and the increase in purchases and use of smaller forestland properties for rural homes, recreation, and hobby forests and farms (Larson, 2004).

\section{Understanding and managing trends in land ownership.}

There have been several national efforts to identify and understand trends in private woodland ownership (Josephson \& McGuire, 1958; Birch et al., 1982; Birch, 1996). Of popular relevance, the National Woodland Owners Survey (NWOS) is an effort brought forth by the USDA Forest Service (Butler et al., 2005). Similar to the NWOS the Agricultural Economics and Land Ownership Survey (AELOS) researches insights concerning changes in farmland ownership among different groups of landowners conducted in connection with the Census of Agriculture (Dodson, 2004). The results of these national surveys share several concerns for the future of America's private land, namely transfer of lands and transitions from farm or forest production to rural life style use. 
Analysis of the 1999 AELOS indicates that individuals with less than 15 years of life expectancy own 30 percent of US farmland suggesting that in upcoming years there may an increase in farmland transfers, conceivably changing the structure of farmland ownership (Dodson, 2004). Data collected from the NWOS reveals that inheritors place significantly greater emphasis on production of timber and non-timber forest products than noninheritors do, as well as the provision of a legacy for their heirs (Majumdar et al., 2009). Non-inheritors attach greater importance to non-timber benefits, such as esthetics, privacy, protection of biodiversity, and non-hunting recreation. Inheritors are much more likely than first-generation woodland owners to be motivated by the opportunity of passing along a legacy of woodland to their children or heirs (Majumdar et al., 2009; Conway et al., 2003). Non-inheritors place significantly more importance than multigenerational woodland owners on the following motivations for owning their woodland for privacy, as part of their home, esthetics, protection of biodiversity, and for recreation other than hunting or fishing (Majumdar et al., 2009).

Many landowners with urban backgrounds and lifestyles are less likely to participate in standard public forestry programs because these programs do not meet their landowning objectives (Sampson \& DeCoster, 2000). Landowners owning farms for retirement or a hobby rather than career-based production are known as hobby farms. On a per acre basis, farmland values for hobby farms exceed those of other small farms, possibly reflecting the added value by their dwelling or an urban influence (Dodson, 2004). 
Differences between production and living values, among others, can cause social conflict between rural and urban landowners, and require consideration and adaption to these interests by local planners and professionals when enforcing regulations, and anticipating the effect on the landscape (Egan \& Luloff, 2000). It is also important to target the right audience when promoting programs. For example Ma et al. (2012) found that participants of cost-share programs who own forestland for reasons other than farming or ranching, and plan to harvest saw logs or pulpwood in the future may be more inclined to participate in forest certification programs. For a review of certification programs see (Overdevest, 2010; Upton \& Bass, 1995).

\section{Farmlands and Woodlands}

An increased diversity of landowners is met with an increase in our gaps of understanding what motivates these landowners to continue to own and manage their land (Erikson, 2002). Many studies of private forestlands inquire of landholders' their priorities and management activities with a primary focus on forests (Ma et al., 2012; Butler \& Leatherberry, 2004; Karppinen, 1998) however, landowners often possess parcels with several land cover types including croplands and pasturelands (Busck, 2002). Heterogeneity among farm operators and US farms is well documented (Hoppe et al., 1999). There is extensive socioeconomic variability among farms, farm operators, and farm households. 
There is a strong link between forestry and farming (Zhang et al., 2005). Forest management has often been viewed as a specialization of agriculture, concerning human attention to issues such as pest management (Kareiva, 2007; Zhang et al., 2005).

Silviculture - the understanding of how to grow, maximize growth and return, and manipulate tree species compositions to meet landowner objectives-could be considered the agriculture of trees (Belt \& Campbell, 2004).

Preston (1948) describes that U.S. farmers own 30 percent of all commercial forestland and collectively their management practices have been found to rank the lowest of all owners which makes farm forestry a major challenge. In his guide to farm woodland management, he introduces methods to incorporate forestry into the regular routine activities of farming. Forest ecosystems and agroecosystems differ in management intensity (Noble \& Dirzo, 1997). For example, a landowner may harvest a hay crop once a year, while a timber harvest may happen once in their lifetime.

Farmers have been known to be more likely to harvest and less likely to have environmental and other concerns opposing harvesting (Jamnick \& Becket, 1987). Yet differences such as lifestyle exist between diverse landowners. Haymond (1988) made distinctions between farm and non-farm owners where farmers were more interested in economics and timber production and non-farmers were more interested in the lifestyle enhancement value. Erikson et al. (2002) found both farmers and non-farmers were motivated by aesthetics for retaining their woodlots on their properties, however, nonfarmers valued aesthetics significantly higher than the farmers. 
Some support the idea that agriculture or forestry-related occupations may increase the likelihood of participation because of familiarity with government programs and farm or forestry practices and production factors (Bell et al., 1994; Nagubadi et al., 1996). On the other hand, others suggest that farmers and ranchers (landowners whose livelihood is directly dependent on resource exploitation) may have a strong negative attitude toward conservation (Langpap, 2004; Ma et al., 2010).

Farmers feel responsible for the construction of the landscape, and their farm is more than a landscape, it can be an image of the farmers themselves (Burton, 2004; Leopold, 1939). They often attach their identity to farming, working the land and following particular set of norms that could be changed by policies and educational initiatives. Their identity is tied to a strong stewardship ethic, UK farmer's for example thought of themselves as having a 'gift' for nurturing the land (Burton, 2004). 
Kvarda (2004) analyzed general attitudes and intentions of forest owner behavior toward their forests, comparing "traditional" Austrian farmers and "non-agriculture forest owners," those earning a majority of their income outside of forestry or agriculture. Kvarda compared farmers without forests, sole forest landowners, and farmers with forest through qualitative interviews in a traditional forestry area in Austria "Waldviertel." This research showed that small-scale forests were found to be experiencing changes in ownership linked to the structural development of agriculture and revealed that the shift of forest ownership from farmers to non-farmers through inheritance or other property transfers comprised of small ownerships and were $80 \%$ privately owned. Many of the non-agriculture owners were descendants of farmers and foresters, but did not emphasize the role of the farm or forest for economic survival. This lack of connection to agricultural heritage to the land has policy implications and cross-boundary opportunities for farms neighboring the nonagriculture landowners (Williamson et al., 2003). 
Williams et al. (1994) found British farmers were uninterested in planting trees on their property as part of a government established Farm Woodland Planting Scheme because of the long term commitment, established norms and economic reasons, though, they appreciated the aesthetics of forests on the landscape. Negative responses from British farmers in the Greenwood Community Forest where they were encouraged to become foresters and leisure providers are explained with the idea amongst the farmers that they felt they were not foresters (Burton, 2004). A resistance to changes in management recommendations and practices could be improved by combining public and private initiatives that benefit rural employment and environmental improvement in future policy (Beedell \& Rehman, 1999).

In contrast, in Finland, families have a long tradition of managing forests alongside farm or off-farm income (Harrison et al., 2002; Bliss \& Martin, 1989). Karppinen's (1998) study of Finnish forest landowner's values and long-term objectives owners indicated that general forest values and long-term objectives of forest ownership are not strongly correlated. His results showed that multi-objective owners, who receive monetary and amenity values from their forestland property, were the most active in their silvicultural improvement. Emphasis on only the economic benefits of forests will not lead to the most active silvicultural and harvesting behavior (Karppinen, 1998). 
Farmers in particular may resist change because they anticipate a loss of identity traditionally granted through existing agricultural behavior (Burton, 2004). Farming gives them their identity and their sense of achievement (Allison, 1996). Understanding the farmer's opinions and managing options to integrate both conservation and production ideas will be key in moving forward in landscape scale management.

The long-term sustainability of these ecosystems and the social and ecological services they generate depend on the conservation of biodiversity on a landscape scale (Tscharntke al., 2005; Bengtsson et al., 2003; Loreau et al., 2003). A gap in understanding may exist between landowners owning both farmlands and woodlands and methods to reach these landowners to achieve landscape level management considering woodlands, croplands and pasturelands on the parcel level.

\section{Cross-boundary Management}

Demands for residential, urban, and industrial development threaten the quality and extent of working landscapes (Egan \& Luloff, 2000; Dwyer \& Childs, 2004). The needs and activities of humans impact natural systems, even on the borders of otherwise 'protected areas' like the management of properties along borders of national parks (Pimentel et al., 1992). 
There is a need to conserve and manage ecosystems across multiple spatial scales

(Rickenbach et al., 2011). There are many avenues to achieve ecosystems management and many definitions exist. Yaffee (1999) defines ecosystem-based approaches as those that consider landscape scale systems (abiotic and biotic) in geographic units but emphasizes working with a deeper understanding of the complexity of these systems and find success in adjacent landowners considering interconnectedness.

One strategy to provide for both ecosystems services and landowner interests is to work collaboratively beyond privately owned property parcels (Crow \& Harper, 2006).

Rickenbach et al. (2011) define cross-boundary cooperation as "voluntary behavior whereby one or more landowners account for the plan and practices on adjacent and/or nearby properties." Working landscape management, and sustainable forestry on mixed ownership landscapes of private and public lands requires people to work together on some level in cross-boundary efforts (Rickenbach \& Reed, 2002).

The United States Forest Service (USFS) uses landscape scale conservation measures in a relatively new policy approach to manage multiple uses, various management objectives, and diverse partnerships in order to face challenges such as climate change (Tomosy et al., 2012). Integral to this effort is the natural processes and social systems of the ownership and geographic area of a landscape. This approach considers a broad landscape scale when addressing solutions to problems in order to provide flexibility and acceptable risks (Tomosy et al., 2012). 
A landscape vision is essential to the conservation of ecosystem services on working landscapes (Goldman et al., 2007; Tscharntke et al., 2005; Firbank, 2005; MA, 2003). The land across boundaries in forested areas is not always contiguous forestland. Forest landowners may own land with other designated uses, such as farmland. Since neither ecosystems nor landscapes end on property boundaries, private lands should also be considered when designing public policies to incentivize management of at larger scales (Finley, 2006). The medley of small private properties that have been typically targeted by a framework that focuses on parcel level management offers challenges to efforts beyond a landowner's fence lines (Rickenbach et al., 2011).

Many threats to these landscapes transcend boundaries beyond a landowner's parcel level, including water pollution, wildfires, and invasive species (Zedler, 2003; Fischer \& Charnley, 2012). Managing individual woodland owner parcels or through a farm-by-farm basis, as most common incentive program model encourage, is inadequate because this spatial unit of management does not generally commensurate with the spatial scale (the landscape) of the service to be generated (Campbell \& Kittredge, 1996; Rickenbach \& Reed, 2002; Lant et al., 2005). One design to address conservation qualities, such as projecting clean water and reducing soil erosion, and threats such parcelization, fire and development in a multistakeholder method is called a landscape scale conservation approach (McKinney, et al., 2010). 
Natural resources agencies and education efforts will need to consider the diversity of landowners on the landscape; their diverse issues, concerns, trust of neighbors, apprehensions and perceived risk of participating in such an effort (Fischer \& Charnley, 2012). Some barriers to cross boundary cooperation include a resistance to change, lack of resources, lack of knowledge and lack of understanding of what is required from participants in the process (Jacobson et al., 2000; Leong et al., 2011).

While barriers exist, overall, previous work indicates broad potential interest from the "average" non-industrial private forest owner (NIPF) in cooperating at scales that span larger geographic areas (Finley et al., 2006). Success in navigating this diversity with these properties offers many opportunities and benefits through projects that provide substantial social, ecological and economic value (USDA FS, 2009).

Recent research has begun to explore attributes associated with landowner willingness to engage in cross-boundary conservation efforts (Finley et al., 2006). The search for attributes that might indicate a landowner's willingness to engage in a collaborative, landscape-scale project is an important part of federal, state, and local agencies to market conservation programs to landowners.

Finley et al. (2006) identified four segments of private forest owners with different levels of interest in cross boundary cooperation. They suggested that identifying interest in cross boundary management could help the development of responsive initiatives that could promote cross-boundary cooperation for landscape scale conservation efforts. 
Bergmann \& Bliss (2004) explored opportunities and challenges of cross boundary efforts with public and private forest managers in Oregon's John Day Valley. The Valley's economy is heavily dependent on cattle, timber, recreational hunting and is $60 \%$ publicly owned bringing about a widely viewed distinct public-private dichotomy idea of ownership. They found the role of private landownership in landowner identity and independence to be significant in their interest in cooperative fire management (Bergmann \& Bliss, 2004).

In the Rocky Mountains of Montana a community partnership of ranchers practice management techniques that require cooperation, contributing to a sense of community and common good (Yung \& Belsky, 2006). Yung and Belsky (2006) found ranchers were primarily concerned about relationships with neighbors and the needs of the local community while new landowners were concerned about environmental protection on their own property and a broadly defined national or global public interest (Yung \& Belsky, 2006). These differences created some conflicts and misunderstandings, which could limit opportunities for cross-boundary conservation. Yung \& Belsky (2006) found new landowners and long-term owners/ranchers agreeing on wanting to keep properties whole and managing for the public good on private lands. However, these two groups disagreed on hunting rights as ranchers described a moral obligation to allow hunting access for the benefit of the community while existing landowners wanted to protect wildlife for an undefined public and did not share the felt obligation to allow access. 
Prospects for cross-boundary cooperation in other regions could benefit from a comprehensive analysis of the history, land tenure, political economy, and ideological patterns of the area under study (Bergmann \& Bliss, 2004). Cross-boundary cooperation is critical to most conservation efforts in mixed-ownership landscapes (Bergmann \& Bliss 2004). Moving forward requires understanding factors that hinder and those that create opportunities for cross-boundary collaboration (Wondolleck \& Yaffee, 2000).

\section{Sense of Place}

One of the complexities to working on and ecosystem management level is the diversity of lifestyles, emotions, meanings and relationships associated with people and the land (Williams \& Stewart, 1998). This presents the challenge of integrating humans as part of the ecosystem (Machlis et al., 1997). Connectedness to nature is the extent to which an individual feels that he or she is a part of nature (Schultz, 2001). Connectedness, attachment, satisfaction, and meanings each contribute to a person's willingness to engage in behaviors that maintain or improve valued attributes of a setting (Stedman, 2002). Sense of place can be conceived as a "collection of symbolic meanings, attachment, and satisfaction with a spatial setting held by an individual or group" (Stedman, 2002). There are three main dimensions to sense of place: place identity, place attachment and conservation ethic (Davenport \& Anderson, 2005). 
There is growing evidence that environmentally significant action increases with affective attachments to and identification with nature and place. (Gosling \& Williams, 2010). Sense of place can be the shared language that eases discussions of the many issues and concerns facing landscapes and matches principles underlying ecosystem management (Williams \& Stewart, 1998).

Cross et al. (2011) described the unique sense of place developed around working landscapes amongst agricultural landowners in a study of their attitudinal and demographic characteristics. Cross et al. (2011) found place identity, conservation ethic, and economic dependence to be distinct dimensions of sense of place amongst agricultural landowners. Cross et al. (2011) concluded conservation ethic should not be assumed to result in the support of a conservation program, policy or other initiative.

Williams \& Stewart (1998) explain that understanding sense of place in natural resources, and the roles of social forces and politics, in a process of competing sense of place (recreationists voicing opinions of new use, local commodity interests wanting to maintain a way of life etc.) may be the most integrative approach to ecosystem management. Both sense of place and ecosystem management by recognizing society's values in nature beyond yields, and both a historic and geographic context that guides management decisions (Williams \& Stewart, 1998). 
Davenport \& Anderson (2005) used place-based meanings as a framework for understanding complex and contentious issues amongst farmers, ranchers and community members in the Niobrara National Scenic River. This provided a method to validate public perspectives and facilitate public engagement during the project planning processes (Davenport \& Anderson, 2005). High levels of place attachment, characterized through patterns in sense of place analysis, generally result in greater commitment to community, positive well being, and increased residential stability (Cross et al. 2011; Gerson et al., 1977; Hummon, 1992; Shumaker \& Taylor, 1983).

A unique sense of place may have developed and persevered in West Virginia during the new culture that emerged in the coalfields during the industrialization period in America (Lewis, 1993). West Virginia was a transitional culture hybrid from pre-industrial agricultural roots and adaptions to new industrial islands (coalfield dominated infrastructure) surrounded by a rural landscape (Lewis, 1993). Retention of the agricultural customs of the migrants in this particular industrial environment was a rational cultural and economic adjustment, which resulted in today's persistent kind of rural-industrial landscape (Lewis, 1993). This unique place relationship can therefore fulfill an important role in the conservation and restoration of landscapes (Naveh, 1998). 


\section{West Virginia}

West Virginia is a geographically diverse state (North, 1986) creating a broad canvas of opportunities and issues for land management. West Virginia is bordered in the West by the Ohio River Valley counties; in the south by coalfield counties bordering Kentucky and Virginia; the northern panhandle near Pittsburgh, PA; the eastern mountain counties reach elevations over 4,000 feet; and the eastern panhandle counties, part of the Potomac River and Chesapeake Bay watershed (Perro, 1975; WVDOF 2010).

West Virginia is mostly rural, primary land uses include agriculture, forestry, coal, oil and natural gas (Shi, 1997). The state's forests are 88 percent privately owned by individuals, corporate businesses, farmers and the forest products industry (WVDOF, 2010) (see Figure 1).

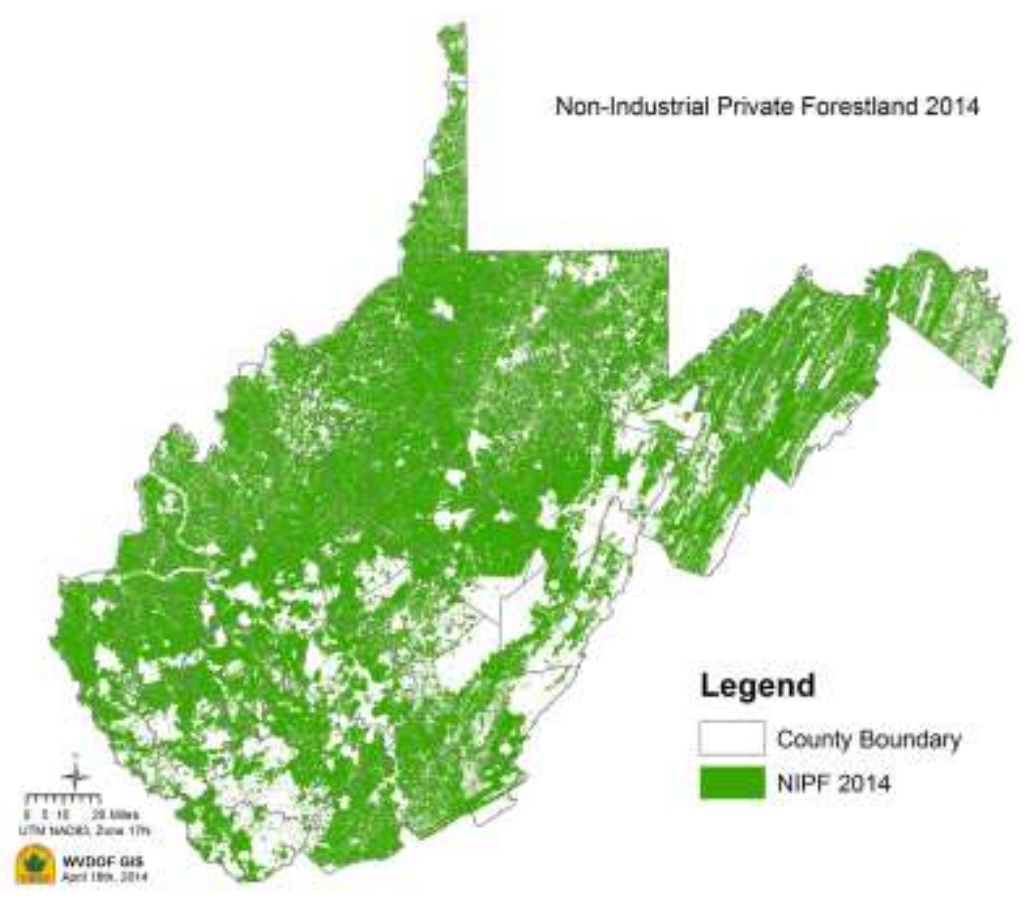

Figure 1: West Virginia Non-Industrial Private Forestland 2014 State Assessment (Map by: Steve Harouff, GIS Specialist, West Virginia Division of Forestry). 
In West Virginia 95 percent of farms are family owned and nearly 80 percent of West Virginia's farms sales are less than $\$ 10,000$ (NASS, 2012). The average farm size in West Virginia is 168 acres, compared to the 434-acre national average, making feasible, small scale enterprises necessary for the preservation of the agriculture industry (NASS, 2012). Most of these farms are small, part-time farms and are investments, or places to live, with additional off-farm incomes rather than current sources of income. Most receive relatively low net returns per acre (Shi, 1997). Lewis (1993) argues that many retired/redundant coal miners that remain from periods of restructuring fell back on the 'make due' culture of growing gardens, raising livestock and barnyard fowl, bartering and labor-swappingcustoms based on an agricultural past, who may not consider themselves or be recognized by the US Census as farmers.

Development pressure in West Virginia has had more overall impact on farmland than forestland (Hart, 1968). Much of the forestland historically cleared for agricultural land, has returned to forests (Rice \& Brown, 2010). Also of concern is the process of intergenerational transfer, since conversion to non-forest uses and/or reduction in forest parcel size often occurs when land is passed from older family members to younger family members (WVDOF, 2010). 
Land conversions away from forestland may be caused from land development, mineral extraction, and wind farms (Barnes et al., 2001). Agriculture, which was once a competitor with forestland, is now threatened by similar competition (Alig et al., 2004). Uncontrolled development and increased recreational use could result in undesired environmental impacts in the area (EIS, 1989). When and where agriculture as an industry and a working land use is threatened, forestry will likely be impacted as well (Turner et al., 2003; WVDOF, 2010).

The WVDOF's Statewide Forest Resource Assessment describes seven sub-issues which are discussed within the Competing Land Uses section. These sub-issues include fragmentation and parcelization, urbanization, population growth, conversion to non-forestry use, mineral extraction, agriculture, and property taxes. Agricultural watersheds in particular have received a great deal of attention and government funding to reduce impacts of farming on water quality in the past 15 years (Boyer, 2005). Two federal programs in West Virginia included the President's Water Quality Initiative of 1989 authorized by the Food, Agriculture, Conservation and Trade Act of 1990 (PL 101-624) and EQIP (Government Printing Office, 2003).

\section{Greenbrier River Valley}

In areas where working lands are being lost to development, pressures against other working lands increase. In a state where much of the best farmland lies in valley bottoms, the conflicts between working lands and developed land uses are severe (WVDOF, 2010). 
One such valley, along the Greenbrier River, relies on forestry production more than the state average, as well as an area valuable for its ecological diversity, agriculture, recreation, and culture (Perro, 1975). The Greenbrier River Counties' agriculture properties and woodlands are owned and operated as farms, as idle lands, and a range of levels of management intensity, which causes increased diversity on the ownership of the landscape and the management actions that are carried out.

A balance of economic development, and environmental protection and quality is sought after in the world's largest cities to the smallest communities (LaPierre \& Germain, 2005). The small communities of the Greenbrier River Valley have pressures for agricultural, forest and recreational productivity. There is also widespread desire to protect the Greenbrier River, keeping its natural character and fears of federal management, projects (EIS, 1984).

The Greenbrier River watershed was nationally selected to receive special funding under the President's Water Quality Initiative for research, voluntary cost sharing, and technology transfer in order to alleviate contamination problems associated with agriculture (Boyer, 2005). The area has received funding under the EQIP program with funds focused on practices concentrated on controlling nutrients and animal wastes such as animal watering systems, rotational grazing and streambank protection (Boyer, 2005). 
Natural resource issues in the area include concerns for water quality, flooding, algae, fecal coliform contamination (TMDL, 2008). The area is also within the areal extent of the Marcellus Shale, a source of natural gas, underlying the states of New York, Pennsylvania, West Virginia, and eastern Ohio ranges (Milici \& Swezey, 2006).

Although the true natural gas producing potential of the Marcellus Shale will not be known until a significant number of wells are drilled (USGS Fact Sheet FS-009-03). The prevalence of natural gas extraction in the area as has been explored (Patchen et al., 1978) and landowners in the area predict development of that infrastructure, a pipeline. Some see opportunity with the influx of natural gas business (Kargbo et al., 2010). Others feel shalegas development could increase industrial activity in the area, alter economic activity, housing and community resources in addition to potential impacts to air and water quality, sound and night sky resources (National Park Service, 2009).

\section{Collaborative Management}

The West Virginia Department of Natural Resources has indicated interest in cooperative management for the area, specifically north of Caldwell (EIS, 1989). During a study on the Greenbrier River for potential Federal designation for Wild and Scenic River protection, great interest in protecting the river was expressed. The federal designation was met with a lack of agreement on how to protect the natural character of the river, with minimal management change (EIS, 1989). 
In 1993, West Virginia established the Watershed Conservation and Management Program that provided strategic vision for ecological assessment and support for grassroots associations (Constantz, 2000). These groups (90 associations with 8 to 250 members) are dealing with numerous landscape issues such as nonpoint sources of pollution, sewage, water quantity, and land management across the state (Constantz, 2000). There are also several watershed associations for the Greenbrier River Watershed including the Greenbrier River Watershed Association, Upper Knapps Creek Watershed Association, and Friends of the Lower Greenbrier River (TMDL, 2008).

Some evidence of collaboration for environmental and social concern for the areas issue exist. For example, the Greenbrier River Watershed Association has held meetings to explain the proposed Mountain Valley Pipeline and the Atlantic Coast Pipeline's effects on the environment and property rights and values, and safety issues. Both of the proposed pipelines would cross the Greenbrier River (Clark, 2014). A past attempt at a National Wild and Scenic River designation was a concern to landowners because of the fear of eminent domain and reduction of property rights (EIS, 1984).

\section{Significance of Study}

This research attempts to bring about awareness for the potential cooperative planning that is needed for landscape level management efforts as many federal programs and groups and more importantly, what motivates landowner decisions in rural West Virginia. 
There are few studies that consider combined agricultural land-uses for conservation purposes (Groot et al., 2007). These combined land uses may be key to working with increasingly smaller parcels of land. Too little is known about agriculture's impact on landscapes, and the economic value of ecosystem services provided by agriculture (Robertson \& Swinton, 2005). New opportunities for landscape-scale environmental management may emerge, by understanding landowners' intentions in managing forests and agricultural lands, together on a landscape level.

The diversity of land management preferences can have positive implications for biodiversity and conservation (Hyttinnen et al., 1999; Robertson \& Swinton, 2005). Exploring the conservation actions and affinities of woodland and farmland owners might provide a way to reach owners by better identifying and understanding associations between the diversity of their attitudes and interests in conservation.

Following Rickenbach et al. (2004) recommendations to pay close attention to the ownership patterns and the motivations and intentions that guide the land's use we consider the unique sense of place, interests, demographics and history of the Greenbrier River Valley in southeastern West Virginia. When working in this landscape of forests and agriculture lands we attempt to identify cross boundary interests amongst the landowners. Conservation efforts and the benefits that they accrue can only be effective in the long term through the support of the farming community in agricultural areas (Burton, 2004). 
The objectives of this research are to explore how the conservation attributes and willingness to participate in cross-boundary conservation of landowners in the Greenbrier River landscape in southeastern West Virginia are related to landownership and property characteristics, personal sense of place, and demographic attributes. 


\section{Chapter 3: Methodology}

This chapter provides information about the area, methods and materials used in this study. First the study area, the Greenbrier River Landscape, is defined with details ranging from location to characteristics of the region. Next the process of selecting a sample population of landowners using the West Virginia Tax database is described. Finally the mailed questionnaire instrument design, distribution, procedures and data analysis are explained.

This study aims to understand the conservation attributes and future conservation directions of these lands with a comparison of West Virginia landowners owning primarily woodlands and those owning combined woodland and farmland. This is an effort to reach working landowners and to explore more efficient uses of the WV tax database for outreach education purposes.

\section{Study Area}

West Virginia is a diverse state bordered in the west by the Ohio River Valley counties, in the south by the coalfield counties of Kentucky and Virginia, in the northern panhandle near Pittsburgh, PA by the Ohio River, and in the east by the streams of the Potomac River and Chesapeake Bay watershed (Perro 1975; WVDOF, 2011). Between these borders are the eastern mountain counties reaching elevations over 4,000 feet. 
In the southeastern part of West Virginia the Greenbrier River winds nearly 200 miles through the Allegheny Mountains, beginning at headwaters in the town of Wildell in northern Pocahontas County and meeting the New River in Hinton at the southern end of the New River Gorge (Rada, 1980). The Greenbrier River Valley is bordered in the north by the Monongahela National Forest in Pocahontas County and Virginia in the south along Monroe County (see Figure 2). This region encompasses the Greenbrier River watershed, a watershed of 1, 656 square miles (EIS, 1986).

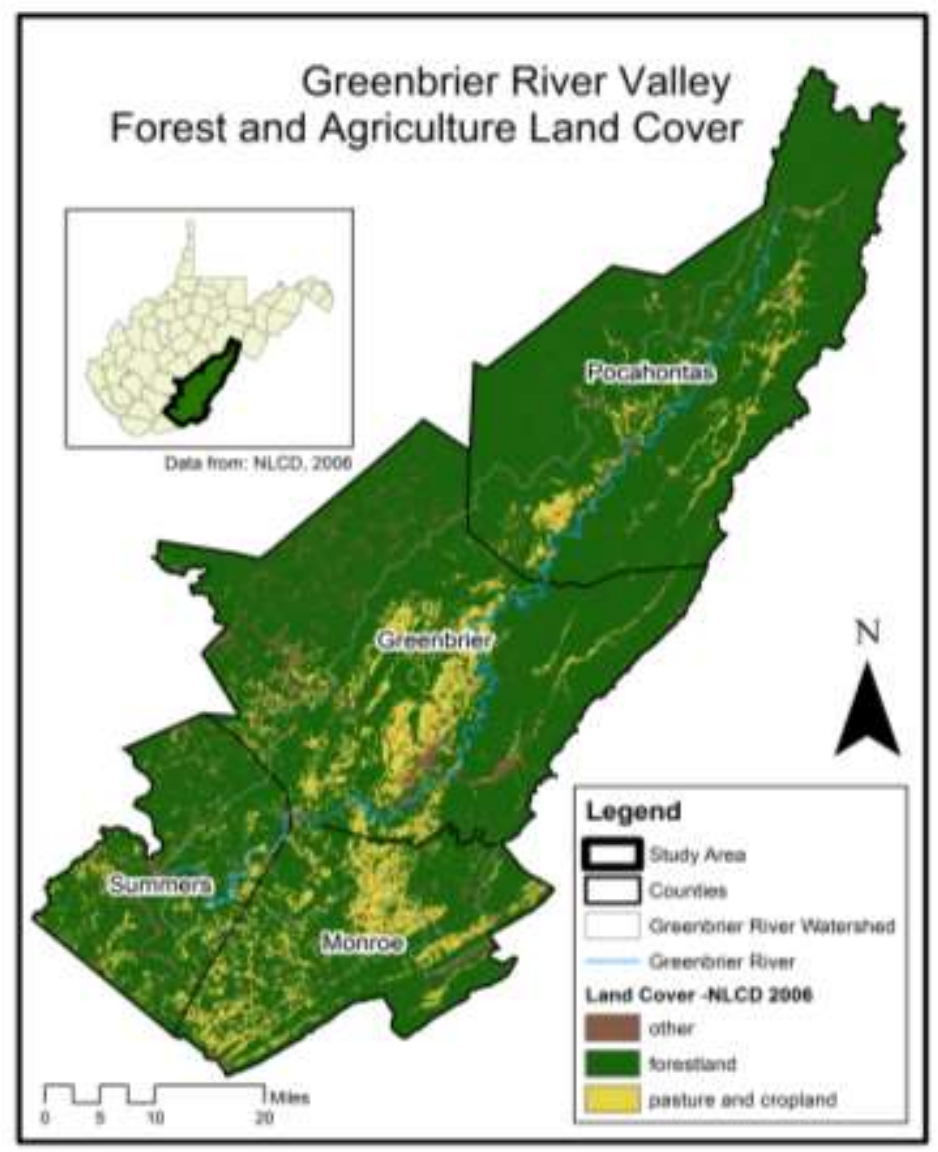

Figure 2 - Greenbrier River Valley Landscape-map featuring agriculture and forestland cover in the study area. 
The Greenbrier River landscape of southeastern West Virginia is predominant in farming and consists of undeveloped rural land as well as rugged and remote north, central and southern hardwood dominated forestland (EIS, 1986). Roughly 250 miles from Washington D.C., the area is valuable for hunting, recreation and tourism including white water rafting (Constantz et al., 1998). Public recreation areas and amenities include the Bluestone National Scenic River, the Greenbrier and Seneca State Forest, Greenbrier River Trail, Cass Scenic Railroad and Greenbrier Valley Railroad, and the world famous Greenbrier Resort (WVDOF, 2010; EIS, 1989; North, 1985).

The Greenbrier River landscape encompasses a four-county area: Summers, Greenbrier, Monroe and Pocahontas. The four-county area was previously studied as part of an Environmental Impact Statement for potential designation of the Greenbrier River as part of the National Wild \& Scenic River Study from the headwaters to its confluence with the New River (EIS, 1989). For this study, parcel level spatial data was unavailable resulting in the use of a four county study area that encompasses the Greenbrier River, the Greenbrier Valley and surrounding communities as a landscape. 
The West Virginia State fair is held annually in the area in the city of Fairlea (Perro, 1975). Celebrations of small town culture in the region is reflected in the fact that Lewisburg, West Virginia, the county seat of Greenbrier County won Budget Travel magazine's title of "Coolest Small Town in America 2011" (Budget Travel, 2011). Twenty-nine sites in this area have been designated in the National Register for Historic Places relating to railroad and lumber industry, civil war battles and Native American archeological sites (National Park Service, 2015; North, 1985). The area is steeped in rich history from Native American culture, European settlement, the civil war and stories engrained in American folklore (Pocahontas and John Henry) (North, 1985).

Divided by the Ridge and Valley and the Appalachian Plateaus physiographic provinces, a unique geographical feature is the abundance of 1,300 caves-the state's ten longest caves are located in this area (EIS, 1989). The Greenbrier River is one of the last undammed, high quality mountain streams in West Virginia with some of the best examples of the federally listed Virginia spirea (Spiraea virginiana) in the state (WVDOF, 2010). The West Virginia Natural Streams Preservation Act protects portions of the river (Environmental Resources Natural Streams Preservation Act Chapter 22. Article 13. §22-13-4).

Scenic quality of this landscape in central Appalachia includes rugged topography of the river corridor, gentle rolling ridge tops, small farms, hardwood side slopes in continuous cover (EIS, 1989; North, 1986). Small river lots, fishing camps, small summer homes, farms and some larger communities, illustrate parts of the river. The forest is reclaiming remnants of abandoned cement bridges, shanties and past industries (Rada, 1980). 
The population of the counties that hold the Greenbrier River Valley are Summers 13,563, Pocahontas 8,669, Greenbrier 35,644 and Monroe 13,483 counties (US Census, 2012). The majority of the open space in this region is under private land ownership and some large tracts of the Monongahela National Forest. Despite a low population growth between 1990 and 2000 (0.3 percent increase) in the Greenbrier and surrounding New River area, new housing grew at a rate of 3.15 houses per square mile of private forestland, suggesting development, parcelization and fragmentation of forested areas is driven by second/vacation home development in these areas (WVDOF, 2010).

The Greenbrier River Valley Landscape has been selected as the study area to explore issues of parcelization, fragmentation, conversion and conservation of farmlands and woodlands and the future of these lands. The Greenbrier River Valley landscape has competing land uses and is primarily composed of privately owned productive agriculture and forestland. Unique attributes of the landscape, recreational opportunities and the agriculture and timber industry create contrasting pressures for conservation as well as development. Conservation concerns in the area including natural gas pipeline development, flooding, and water quality make this a location with issues pertinent to cross-boundary concerns and of importance for measuring collaborative interests. 


\section{Landowner selection process.}

In West Virginia, the tax database (WVTD) provides a record of landowners and their taxed land-use type, such as pasture, tillable and woodland. These tax records provide a direct mailing contact to West Virginia landowners with forest and farmlands. The WVTD record was used to identify landowners who own at least 1 acre comprised of woodland, pasture, or tillable lands.

Parcel information was obtained with permission from the county tax assessors of the counties of interest who provided a release of the data from the West Virginia State Tax Department (WVSTD). The WVSTD Help Desk Analyst filtered the data for parcels of 10 acres or more and generated electronic copies of Computer-Assisted Mass Appraisal (CAMA) files. The files contained the names and addresses of the parcel owners, parcel size, and recorded land use types in each parcel.

Because the definition of what constitutes "forest" can be vague (Lund, 2002), this 10 acre minimum was requested due to the minimum property size required for landowners to apply for several federal landowner incentive programs and suggests a minimum acreage where active management can occur. The land use types on the West Virginia Tax database

include: 1) homesite, 2) tillable, 3) pasture, 4) woodland, 5) wasteland, 6) primary site, 7) secondary site, 8) residual, 9) waterfront, and 10) undeveloped/unclassified (WVSTD, 2013). 
This project focused on three land types: woodland, tillable and pasture with their definition from the WVSTD definitions. These definitions are:

- Woodland--acres of uncleared wooded land

- Tillable--number or acres of cleared land capable of growing crops

- Pasture--number of acres of cleared land which is not economically suitable for crowing crops but is suitable for grazing livestock (WVDT)

The tax records were processed to eliminate parcels void of woodland, pastureland or tillable land. All remaining parcels included at least one acre of woodland, pastureland or tillable land or some combination of those land types. While these parcels may have contained other types, such as wasteland, this was not considered further. Henceforth, pasture or tillable land will be referred to as farmland or agriculture land. Woodland and farmland parcels in the four counties were aggregated and checked for duplicate names and addresses. Duplicates were eliminated by taking the first occurring record as our sample. Land parcels with names suggestive of corporations or public entities were removed from the sample assuming the owners were not our target non-industrial, private forest owners (NIPF) ownership types. Through this process parcels without woodland or pasture or tillable land were removed the sample assuming that those individual owners were not NIPF or farmland owners. 
A sample population was randomly selected from the aggregate list of parcels that combined all four counties of the Greenbrier River Valley. Each parcel was assigned a random number. Duplicate names or mailing addresses that slipped through the initial screening were eliminated and replaced by another randomly selected parcel from the original list. Duplicate landholdings in multiple counties of the study area was addressed by the questionnaire in question 3. Do you own agriculture or woodland property in other counties in West Virginia or other states? Each selected parcel was given a specific case identifier code made up of the first letter of the county name and an arbitrary number beginning with the number 1001 (e.g. G1001). These numbers were printed in the questionnaires to assure that a landowner who returned a questionnaire was not sent any follow-up mailings. This identifier code helped preserve the confidentiality of the responses by separating the respondent's identifiable information from their responses on the questionnaire.

The population of landowners from the tax record, within the four county region, owning at least 1 acre of farmlands or woodlands included 14330 owners. A sample population of 374 was selected using Krejcie and Morgan (1960) formula for Determining Sample Size for Research Activities. The table uses 0.05 degree of accuracy expressed as a proportion, Chi-square value of 1 degree of freedom (3.841) and 0.50 population proportion. This number was also corrected for expected response rates of $20 \%$. Recent surveys using these parcel data from the WVDT have resulted in response rates of approximately 25\% (McCuen et al., 2013; McGill et al., 2008; Erazo et al., 2014). Corrected for historic response rate of 20\%, 1870 questionnaires were needed to achieve the desired degree of precision. 


\section{Mailed Questionnaire}

A mailed questionnaire was the instrument used to obtain a representative sample of woodland owner conservation, property, and demographic attributes in the Greenbrier River watershed of southeastern West Virginia. The questionnaires entitled "West Virginia Greenbrier River Valley Farmland and Woodlands Survey" were sent to the farmland and woodland owner sample population. One thousand eight hundred and thirty-seven questionnaires were mailed to the sample population.

The questionnaire was developed using terminology and questions that would apply to both agriculture and woodland vocabulary, through review of literature and previous survey work (Cross et al., 2011, Starr \& McConnell, 2014; Kay \& Nelson, 2007; Finley et al., 2006). Two county extension agents and three landowners reviewed the questionnaire, their responses were not included in the final dataset. Five WVU students led by a faculty member with experience in survey work reviewed the questionnaire in a small focus group. Based on suggestions from these groups and the research committee, minor adjustments were made. 
The questionnaire asked participants questions in the following categories; property ownership, land resources and planning, cooperative activities (based on Finley et al. 2006), ideas about your land using a table of questions used in Cross et al. (2011), present and future activities on your land, and demographics. Multiple forms of questions were used including several fill in the blank short answer questions, Likert scales (Likert, 1932), multiple choice, and yes or no. Tables and check boxes were used to organize the 25 questions in the five-page questionnaire (see Appendix).

The survey questions were adapted from previous questionnaires based on similar topics from published research (Starr \& McConnell, 2014; Cross et al., 2011; Kay \& Nelson, 2007; Finley et al., 2006) as well as from recent studies conducted at West Virginia University (Erazo et al., 2014; Fegel et al., 2014; McCuen et al., 2013).

Using a modified Dillman method the questionnaires were mailed out in a multi-step survey process (Dillman, 1978). A pre-survey postcard notifying landowners a questionnaire would be arriving in the mail was as sent of January 5, 2015. The first mailing of the questionnaires on January 7, 2015 included an introductory letter requesting for landowner participation in the survey. The questionnaire included a brief description of the surveys use and goals for understanding landowner educational interests and management motivations. On January 23, 2015 a reminder postcard was sent to nonrespondents requesting if they had not yet done so already, to return the questionnaire (appendix). A second questionnaire was mailed on February 5, 2015 to non-respondents, with a cover letter requesting their response. 
Two small modifications were made to the second questionnaire. The first was a correction of a spelling mistake to change "Tail to trail" on question 20 and the second remedied an accidentally split question in question 17 . The item in question 17 "Land in my community offers the natural amenities I am looking for in a place to live" from Cross et al. 2011 was inadvertently split into "Land in my community offers the natural amenities" and "I am looking for in a place to live" in the first questionnaire due to a formatting error. In the second questionnaire this item was corrected to the intended format and the item "I am looking for in a place to live" was removed from the Principal Components Analysis detailed in Chapter 3, for details on the management of this error in the analysis section.

\section{Data Analysis}

Statistical analyses were completed using SAS Software (SAS, 2000-2004). Estimates of frequency and relative importance were measured with the quantitative survey questions. The open-ended questions attempted to complement the study using variables identified by the landowners rather than the surveyor's intuition and previous surveys (Bliss \& Martin, 1989). The fill in the blank questions were coded using the conventional approach for open-ended questions, allowing themes to flow from the data (Hsieh \& Shannon, 2005). The coding was checked by the Primary Investigator Dave McGill and by a peer to ensure credibility and consistency of coding (Miles \& Huberman, 1994; Thomas, 2006). Significance levels were set at \pm 0.05 for hypothesis testing. 


\section{Assessment.}

Variables related to cross boundary cooperation and cooperative activities were treated as response variables in line with the goal to assess conservation intentions of private landowners in the Greenbrier River Valley Landscape. Associations between these response variables were modeled using "explanatory" variables from the questionnaire such as residency, education, parcel size, and farm status. Explanatory variables of particular interest include ownership of agriculture property and sense of place.

Responses from the mailed questionnaire were entered into in an Excel spreadsheet. Each survey was entered in the Excel spreadsheet by recording the answers, survey identifier code, and the date received. Questionnaires began with four screening-entry questions (not numbered):

I. I do own woodland or agriculture property, II. I do not own woodland or agriculture property, III. I prefer not to participate in this survey, and IV. Please send me a summary of the results of this survey. The response rate was calculated by dividing the full and partial responses received by the sample size sent (deducting ineligible responses) following definitions of the Association of American Public Opinion Research (AAPOR, 2011). Cooperation rate was calculated by diving the dividing the full and partial responses received by the sum of refusals, full and partial responses received. 
Response types for the questionnaires were classified based AAPOR (2001) definitions: $\mathrm{PR}=$ partial response, $\mathrm{FR}=$ full response, $\mathrm{RF}=$ refusal, $\mathrm{BA}=$ bad address, $\mathrm{IN}=$ =ineligible (has sold property or does not own woodland or agriculture property) and $\mathrm{D}=$ deceased. To determine the requirements for these responses the AAPOR Standard definition was used: "less than $50 \%$ of all applicable questions answered (with other than refusal or no answer) equals breakoff, $50-80 \%$ equals partial, and more than $80 \%$ equals complete." Break-off was treated as refusal. Questionaries' from the first mailing that the postal service returned with a "forward time exceeded " sticker and new address (43) were mailed with the new address in the second mailing. Bad addresses were recorded when returned by the postal service with a sticker indicating "Bad Address," "Unable to Forward," or "No Such Person."

Nonresponse bias was evaluated by the combination of two procedures outlined by Finley et al. (2006) and Lindner et al. (2001). This consisted of two methods:

a) Comparing respondents with non-respondents by one common attribute.

b) A comparison of key questions made between early and late respondents. Common attributes selected to compare respondents with non-respondents was woodland and agriculture acreage owned (from the tax WV database). Using the logarithmic transformation of agriculture land (LNAGAC) from the 2013 tax records, analysis of variance (ANOVA) indicated there were no statistical differences between the two groups ( $\mathrm{F}=0.66 \mathrm{P}=0.416)$. Similarly, for woodland acreage LNWAC, analysis of variance (ANOVA) indicated there were no statistical differences between the two groups $(\mathrm{F}=0.09 \mathrm{P}=0.760)$. 
Early respondents (the surveys received from respondents answering before February $6^{\text {th }}$ ) and late respondents (those who responded after the second questionnaire was mailed on February $6^{\text {th }}$ ) were compared using key variables from the sense of place principal component analysis and cooperative attitudes and activities. These variables included: CONSETHIC, ECONDEP, CONEASE, and ECOHEALTH. The comparison between CONSETHIC found no statistically significant differences $(\mathrm{F}=1.040, \mathrm{P}=0.309)$. The comparison between ECONDEP also found no statistically significant differences ( $\mathrm{F}=0.530 \mathrm{P}=0.4687)$. ChiSquare tests for independence were not significant for the variables CONEASE ( $\mathrm{P}=0.195$, $\left.\chi^{2}=1.71\right)$ and ECOHEALTH $\left(\mathrm{P}=0.807, \chi^{2}=0.059\right)$. Based on these tests there was no significant difference found between respondents with non-respondents, as well as early and late respondents.

Several decisions were made when entering the survey answers. Some landowners indicated in survey comments that they received their survey with the past owner's address that was still in the tax database. These responses were entered. Some respondents' tax records had multiple names; if the respondent answered in-lieu of a deceased participant their responses were accepted. If a response was received without the case code, a new code was generated and the response was used. In the same question 2 chart if multiple year acquired (e.g. 1950 \& 2001) the oldest year acquired was used. In cases where a respondent owned property in more than one of the four counties of the study area their responses were used but their ownership as a 100\% agriculture owner, $100 \%$ woodland owner or mixed agriculture and woodland was calculated based on in the tax database amount. 
To preserve the data delivered by the questionnaire all respondent comments were written as notes in the Excel spreadsheet. These comments may be helpful in future planning for questionnaires indicating places where respondents felt they needed to explain in more detail or more space to better describe their response.

\section{Key response variables.}

Five key response variables (excerpted from Finley et al. 2006) were used from the Cooperative Attitudes and Actions section of the questionnaire. Two questions indicated their position on the following statements: "Do you consider the ecological health of neighboring or nearby properties when making decisions concerning your land?" (ECOHEALTH), "Have your neighbors or owners of nearby properties spoken to you about their management decisions?" (MGMTDEC), with the response options often, sometimes, rarely or never. These two questions stood alone in Finley et al. (2006) principal component analysis and as such were used as single questions rather than composite in this research to describe cooperation that may already be happening between neighbors and nearby properties. 
Three questions asked the level of interest with the following future cooperative activities "In the future, I would be interested in working with my neighbors to write a conservation easement agreement to protect more than one ownership from development" (CONEASE), "In the future, I would be interested in asking my neighbors to join a group to lease hunting and recreation access to our shared properties"(ACCESS), "In the future, I would be interested in talking with my neighbors about managing wildlife habitat together" (HABITAT) with the response options very interested, somewhat interested, neutral, somewhat uninterested, or very uninterested.

The response variables serve as indicators of conservation attributes of respondents and landowners' willingness to participate in cooperative activities. These items were selected based on the literature review of relevant issues in the area including past attempts in recreational development. The suggested cooperative attitude and action (ECOHEALTH, MGMTDEC) were selected to provide a measure of landowner's present interaction with the neighbors, that is, whether they are already interacting at some level. The future cooperative activities (HABITAT, ACCESS and CONEASE) were selected to provide a measure of landowner interest in allowing access on properties for recreational or hunting leases, cooperative interaction in developing habitat and conservation easements. 
Conservation easements are a legal instrument that can protect working farms and woodlands from negative impacts of parcelization and fragmentation. These landscape level processes continue to be an issue that substantiates the need to create, protect and enhance wildlife habitat across property boundaries (Marcouiller et al., 2002). Wildlife habitat was selected as a future cooperative activity (HABITAT- (In the future, I would be interested in talking with my neighbors about managing wildlife habitat together.) These were measured with summated Likert-type scales and converted to binary responses.

\section{Key explanatory variables.}

One key explanatory variables is expected to be type of land cover type owned farmland, woodland or both; this will be checked based on proportion of woodland, tillable, and pasturelands from the tax database. Using a sense of place Likert measurement scale developed by Cross et al. (2011) we will evaluate if economic dependence is a distinct dimension of sense of place amongst other dimensions. Other explanatory variables include gender, age and education, proximity to a town or city and if they own property in another

West Virginia county or other state. Most variables, including the willingness to participate in cross-boundary activities variables (five) were discretized into binary form (1=interested, $0=$ not interested), (1=yes, $2=$ no) based on the median distribution. 


\section{Variable reduction for sense of place.}

The PCA protocol begins with an assessment of opportunities for variable reduction using Spearman rank correlation PROC CORR. The degree of correlation among the variable sets can be used to indicate variable redundancy (Stevens, 1992). To test the significance of correlations the command PROC FACTOR METHOD=ML HEYWOOD, Bartlett's test of sphericity was used. The null hypothesis for the Bartlett's test of sphericity is $\mathrm{H}_{0}=$ there are no common factors , $\mathrm{H}_{0}=$ one factor is enough. Following rejection of the null hypothesis, PCA was then used to evaluate variation in the correlation matrix of the 16 variables for the presence of latent components. In SAS 9.4 (Release 9.4, 2013, SAS Institute: Cary, NC) the procedure is FACTOR, the method is METHOD=PRINCOMP.

The primary selection method to select the number of components was parallel analysis (Patil et al., 2008). Parallel analysis compares the $95^{\text {th }}$ percentile of eigenvalues from randomly generated correlation matrices with correlation matrices under study. Parallel analysis was carried out using a SAS program developed by O'Connor (2000). Variable loadings on given components in the study were tested for internal consistency using Chronbach's $\alpha$ through the SAS procedure PROC CORR $(\alpha>.70)$. 
Likert-type items in question 17, Ideas about your land were written based on Cross et al. (2011). Principal component analysis (PCA) was carried out using SAS to reduce the number of variables to be used in subsequent analyses. PCA is a method that is used to reduce large numbers of correlated variables into small sets of composite variables. The goal of using PCA analysis in this analysis was to produce a representative composite variable for the group while preserving information. Known sense of place (SOP) components are place identity, place attachment, environmental ethic and economic dependence (Cross et al. 2011); these were evaluated with respect to the composite variables developed though our PCA process.

\section{Sense of place principal components analysis.}

The 16 variables used to measure sense of place (Q17a-Q17p) from the methodology of Cross et al. (2011) were found to be significantly correlated with one another. Among the 16 variables and 120 correlations, 100 were statistically significant at the alpha $=0.05$ level.

Bartlett's test of sphericity revealed a significant chi-square value $\left(\chi^{2}=3365.2, \mathrm{p}<.0001\right)$ and led to the rejection of the null hypothesis in favor of the alternative that there is significant statistical correlation among the variables. Given the amount of significant correlation among these items, principal components analysis was conducted to assess the possibility of reducing the number of items to be used as explanatory variables 
Parallel analysis was used to determine the number of components needed to describe the data (Patil et al., 2008). Using a methodology developed by O'Connor (2000) parallel analysis generates a $95^{\text {th }}$ percentile set of eigenvalues from a randomly generated correlation matrices (Figure 3). Eigenvalues which exceed the $95^{\text {th }}$ percentile are thought to be from populations that are other than random.

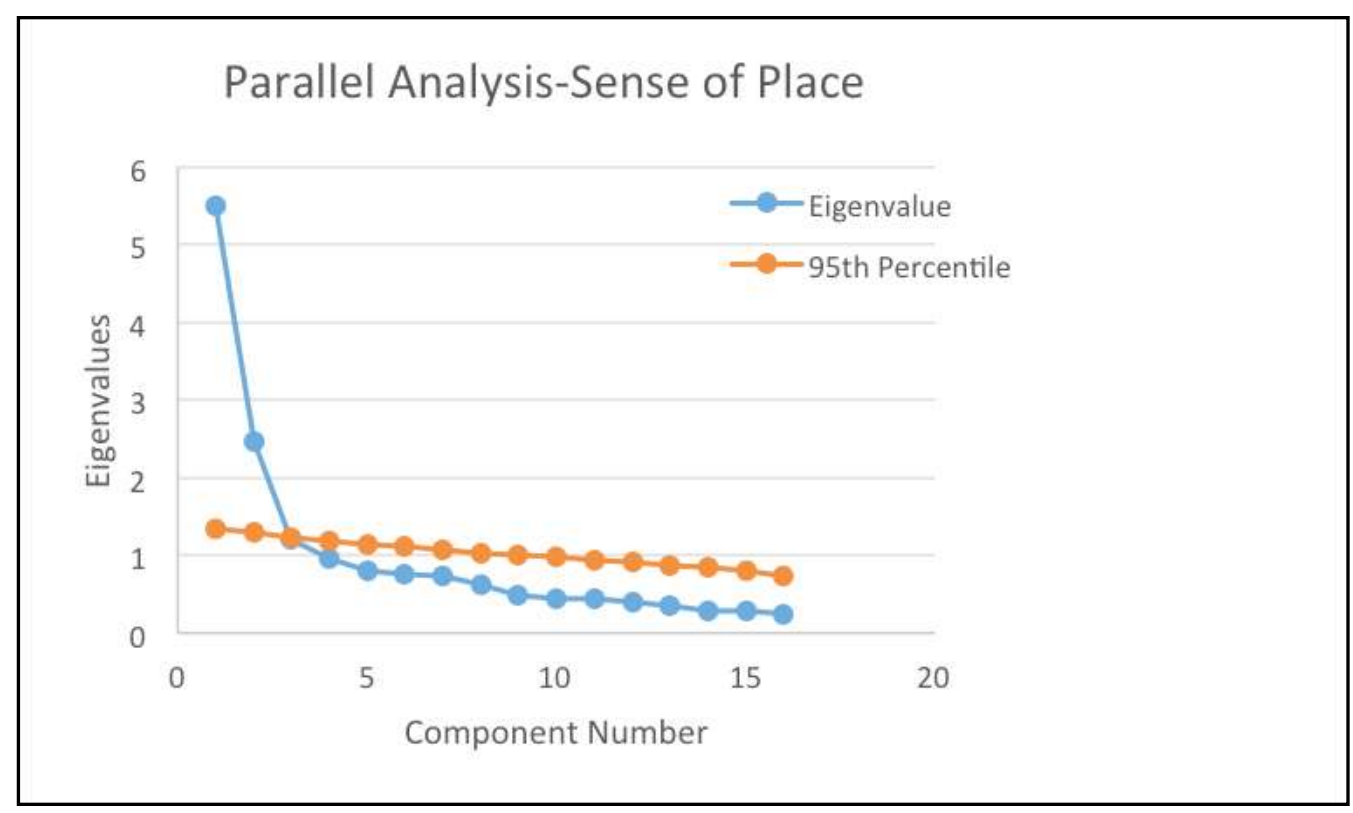

Figure 3: Parallel analysis for sense of place showing eigenvalues of components 1-16 from Greenbrier River Valley farmland and woodland owner questionnaire data and corresponding eigenvalues at the 95th percentile of values generated from random populations. 
Following the parallel analysis the principal components analysis (PCA) was run requesting only two components. The PCA using a Varimax rotation method produced two principal components (Table 1) with the variables NATCHGE (Factor loading .34) and MAXBENIF (Factor 1=.51, Factor 2=.30) failing to load on either of the principal components. These variables were not included in the analysis because of their poor contributions as a predictors and high cross loading for MAXBENIF (Factor $1=0.51$, Factor $2=0.30$ ). In an effort to mirror the Cross et al. (2011) analysis these variables were left out of the regression models. Parallel analysis confirmed the reduction of variables. The first component accounts for $34 \%$ of the variation among the 16 survey items, the second component accounts for $15 \%$.

Cross loading was addressed by focusing on the discrepancy between primary and secondary factor loadings. Items were retained if the difference between the primary and secondary loadings was significantly large (generally $0.3-0.4$ ). Items were considered adequately loaded on a component if the loading on the primary factor was at least twice as large as that of the its loading on the secondary factor. For example an item with a primary factor loading of 0.5 would need have a secondary loading of 0.25 or less (Matsunaga 2010). Significant and complex cross loadings were expected given findings from (Cross et al. 2011). 
Cronbach's Alpha was generated for variables that grouped on a given component to check internal consistency, the degree the set of single items is explained by a single latent component. The resulting scores for the two rotated factor groups was 'good' (component $1=0.89$ ) and (component $2=0.79$ ) George \& Mallery, 2003). Variable grouping obtained was similar to items grouped in Cross et al. (2011). When naming PCA variables we looked at those with higher loadings to name variables after them (Hair et al., 1998) and to reflect the naming of variables known to previous sense of place research from the scale author Cross et al. (2011). The two components that resulted from our analysis were Conservation Ethic (CONSETHIC) and Economic Dependence (ECONDEP). 
Table 1: Survey items related to sense of place and factor structure for PCA with Varimax rotation related to sense of place. Bold loadings of variables on factors indicate most significant for given variable.)

\begin{tabular}{|c|c|c|c|c|c|}
\hline $\mathrm{PC} \#^{2}$ & Variable Name & Description of Survey Item & Factor 1 & Factor 2 & Cronbach's a \\
\hline \multicolumn{4}{|c|}{ “Conservation Ethic” (CONSETHIC) } & & 0.885 \\
\hline 1 & PRESERVE & $\begin{array}{l}\text { Land should be preserved for future } \\
\text { generations* }\end{array}$ & 0.742 & & \\
\hline 1 & IDENTITY & $\begin{array}{l}\text { Personal history and identity are closely } \\
\text { tied to my/our land** }\end{array}$ & 0.542 & & \\
\hline 1 & HISTCHAR & $\begin{array}{l}\text { Agriculture is part of the historical } \\
\text { character of my community* }\end{array}$ & 0.678 & & \\
\hline 1 & CONSNAT & I have a responsibility to conserve nature* & 0.789 & & \\
\hline 1 & GOODSTEW & It is important to be a good steward* & 0.744 & & \\
\hline 1 & BELONG & My community is where I most belong** & 0.616 & & \\
\hline 1 & MYSELF & $\begin{array}{l}\text { I feel more myself on my property than } \\
\text { anywhere** }\end{array}$ & 0.679 & & \\
\hline 1 & SPIRITUAL & $\begin{array}{l}\text { I feel a spiritual connection to where I } \\
\text { live** }\end{array}$ & 0.712 & & \\
\hline 1 & FUTGEN & $\begin{array}{l}\text { Natural amenities should be preserved for } \\
\text { future generations* }\end{array}$ & 0.766 & & \\
\hline 1 & AMENITIES & $\begin{array}{l}\text { Land in my community offers the natural } \\
\text { amenities I am looking for in a } \\
\text { place to live }\end{array}$ & 0.626 & & \\
\hline \multicolumn{5}{|c|}{ “Economic Dependence” (ECONDEP) } & 0.792 \\
\hline 2 & ECONPROD & $\begin{array}{l}\text { My family's livelihood depends on } \\
\text { economic productivity of land }{ }^{* * *}\end{array}$ & & 0.832 & \\
\hline 2 & FLEXILAND & $\begin{array}{l}\text { My future livelihood depends on having } \\
\text { flexible land use*** }\end{array}$ & & 0.846 & \\
\hline 2 & CONCON & $\begin{array}{l}\text { Financial well-being conflicts with plans } \\
\text { for conservation }\end{array}$ & & 0.583 & \\
\hline \multirow[t]{3}{*}{2} & SUPRETIRE & $\begin{array}{l}\text { I am counting on the future value and } \\
\text { productivity of my land to support me in } \\
\text { retirement } \\
\text { **** }\end{array}$ & & 0.787 & \\
\hline & MaxBenef & $\begin{array}{l}\text { I manage land to maximize benefit to my } \\
\text { community** }\end{array}$ & 0.513 & & \\
\hline & NatChge & $\begin{array}{l}\text { If the natural amenities changed I would } \\
\text { not stay }\end{array}$ & 0.341 & & \\
\hline
\end{tabular}

Likert items used here 1=strongly disagree, $2=$ disagree, $3=$ =neutral, $4=$ =agree, $5=$ =strongly agree.

${ }^{1}$ Principal Component criteria for selection set at a minimum of .50.

2 Principal Component numbers from Varimax rotation.

${ }^{3}$ Cronbach's alpha values, selection criteria set at a minimum of 0.70 , survey items with lower values are left to stand alone and were not included in regression models.

* “Conservation Ethic" **"Place Identity"*** "Econ Dependence" **** Added per Cross et al. (2011) recommendation. 
These new composite sense of place variables were converted into binary form (1=higher conservation ethic, $0=$ lower conservation ethic) and ( 1 =higher economic dependence, $0=$ lower economic dependence) based on the measurement of sense of place dimensions created by Cross et al. (2011).

\section{Conservation Ethic}

This category represents two dimensions of sense of place, conservation ethic and place identity. Unlike Cross et al. (2011) where place identity was a separate dimension, here it is merged with the conservation ethic items in the variable reduction process because of the number of recommended factors based on parallel analysis and examination of the cross loadings.

Conservation ethic (CONSETHIC) was developed using 6 items from the questionnaire (see Table 1). This dimension of sense of place addresses both conservation ethic and place identity. Conservation ethic is an ideological relationship with place. This type of relationship (ideological) is based on conscious values and beliefs, either spiritual or ethic of responsibility about how humans should relate to physical places, specifically how to live in a place.

Place identity is a distinct dimension of sense of place but here both conservation ethic and place identity describe experiences that become part of a person's individual and community identity as well as describe how to live. It represents here the affinity with and responsibility for a place. 
In short, conservation ethic describes the dimension of sense of place felt by respondents who define an ethic of responsibility, and identity of stewardship, belonging to the land/community and commitment to managing land and conserve nature for future generations. Conservation ethic is the affinity with and responsibility for a place.

\section{Economic Dependence}

Economic dependence (ECONDEP) was developed using 4 items from the questionnaire (Table 1). This dimension of sense of place replaces the more commonly used recreation place dependence for a description of which a person earns an income from and depends upon the land for financial wellbeing or retirement.

\section{Cooperative Attitudes, Actions and Activities}

The cooperative attitudes, actions and activities were used as response variables to assess a landowner's willingness to cooperate with neighbors. The interest of respondents in suggested cooperative attitudes, actions, and activities were measured using 5 survey items from Finley et al. (2006). All the variables were ordinal and were converted to binary scale. Explanatory variables with statistically significant results (bold values) in relation to the five cooperative activities are presented in Table 4 and 5.

Independent variables (ownership and property attributes, sense of place and demographics) were converted to binary form except for the continuous variables LNAGAC, LNWAC and LNPROXCITY (Table 2). 
Table 2: Description of response and explanatory variables used in logistic regression models.

\begin{tabular}{|c|c|}
\hline Variable name & Description \\
\hline \multicolumn{2}{|r|}{ Response Variables } \\
\hline ECOHEALTH & $\begin{array}{l}\text { Considers the ecological health of neighboring or nearby properties when making decisions concerning their } \\
\text { land (high=1, otherwise } 0 \text { ) }\end{array}$ \\
\hline MGTDEC & $\begin{array}{l}\text { Neighbors or owners of nearby properties have spoken to respondents about their management decisions } \\
\text { (high=1, otherwise } 0 \text { ) }\end{array}$ \\
\hline CONSEASE & $\begin{array}{l}\text { Interested in working with neighbors to write a conservation easement agreement to protect more than one } \\
\text { ownership from development } \\
\text { (high=1, otherwise } 0 \text { ) }\end{array}$ \\
\hline HABITAT & Interested in talking with neighbors about managing wildlife habitat together in the future (high $=1$, otherwise 0 ) \\
\hline ACCESS & $\begin{array}{l}\text { Interested in asking neighbors to join a group to lease hunting and recreation access to their shared properties in } \\
\text { the future (high=1, otherwise 0) } \\
\text { (Finley et al., 2006) }\end{array}$ \\
\hline \multicolumn{2}{|r|}{ Explanatory Variables } \\
\hline \multicolumn{2}{|c|}{ Ownership Attributes } \\
\hline LNAGAC & Natural log of agricultural (pasture and tillable) acreage \\
\hline LNWAC & Natural log of woodland acreage \\
\hline OWNOTHER & Own other woodland or agriculture property (yes=1, otherwise 0 ) \\
\hline LNPROXCITY & Natural log of distance to nearest town/city \\
\hline RESIDENT & Reside on property (yes=1, otherwise 0 ) \\
\hline PURCHASE & Property acquired for purchase (purchase=1, inherit, gift or otherwise $=0$ ) \\
\hline UNIQUEOWNER & (Individual ownership=1, multiple ownerships=0) \\
\hline FARM & Property is considered a farm by USDA definition (yes=1, otherwise 0 ) \\
\hline LEASE & Property is leased (yes $=1$, otherwise 0 ) \\
\hline PRODUCTION & Reason to own responses included farm, production, timber harvest and management (yes=1, otherwise 0 ) \\
\hline \multicolumn{2}{|l|}{ Sense of Place } \\
\hline CONSETHIC & $\begin{array}{l}\text { PRESERVE-Land should be preserved for future generations } \\
\text { IDENTITY-Personal history and identity are closely tied to my/our land } \\
\text { HISTCHAR-Agriculture is part of the historical character of my community } \\
\text { CONSNAT-I have a responsibility to conserve nature } \\
\text { GOODSTEW-It is important to be a good steward } \\
\text { BELONG-My community is where I most belong } \\
\text { MYSELF-I feel more myself on my property than anywhere } \\
\text { SPIRITUAL-I feel a spiritual connection to where I live } \\
\text { FUTGEN-Natural amenities should be preserved for future generations } \\
\text { AMENITIES-Land in my community offers the natural amenities I am looking for in a place to live } \\
\text { ECONPROD-My family's livelihood depends on economic productivity of land } \\
\text { FLEXILAND-My future livelihood depends on having flexible land use } \\
\text { CONCON-Financial well-being conflicts with plans for conservation } \\
\text { SUPRETIRE-I am counting on the future value and productivity of my land to support me in retirement } \\
\text { (Summated variable PCA, yes =1, otherwise=0) } \\
\text { (Cross et al., 2011) }\end{array}$ \\
\hline \multicolumn{2}{|c|}{ Land Resources /Planning } \\
\hline TAXTYPE & Land is taxed for managed timberland or farmland (yes $=1$, otherwise $=0$ \\
\hline CONTACT & Have contacted a forester or agriculture professional (yes=1, otherwise 0 ) \\
\hline PLAN & Have Forest Stewardship Plan or Farm Plan (yes=1, otherwise 0) \\
\hline INCENTIVES & Have heard of or received incentive program payments (yes=1, otherwise 0 ) \\
\hline \multicolumn{2}{|l|}{ Demographics } \\
\hline AGE & Age of respondents in years (associates degree or higher $=1$, some college or less $=0$ ) \\
\hline EDUCATION & Education level of respondents ( 65 and older=1, 64 and younger $=0$ ) \\
\hline FEMALE & Male $=0$, Female $=1$ \\
\hline
\end{tabular}


A missing values assessment with observations in Spearman Correlation Coefficients revealed INCOME and YRAQCUIRED had lower response rates (408 out of maximum 481 responses) than most of the other variables. INCOME and YRACUIRED were removed from the group of independent variables included in the model. Nineteen explanatory variables were included in the model (Table 2).

\section{Modeling Cross-Boundary Conservation Attributes}

Logistic regression analysis was used to assess the relationship between conservation attributes (response variables) and explanatory variables. The Akaike Information Criterion (AIC) was used to estimate the number of variables that provide the least amount of information loss for our data (Mazerolle, 2006). From an AIC standpoint, the lower the AIC, the less information is "lost" for a given model. The minimum AIC (AICmin) was evaluated using PROC LOGISTIC and an "open" stepwise selection algorithm with significance levels for entry 0.99 and to remove 0.95 for each response variable. For each response variable, the number of observations used and AICmin were: ECOHEALTH ( $\mathrm{n}=395$, AICmin 2 covariates), MGTDEC ( $\mathrm{n}=397$, AICmin 4 covariates), HABITAT ( $\mathrm{n}=395$, AICmin 5 covariates), CONEASE ( $n=253$, AICmin 3 covariates), ACCESS ( $\mathrm{n}=397$, AICmin 5 covariates). Once the AICmin was obtained, a best subsets logistic regression (King 2003) provided the best combination of variables for models with AICmin and AICmin \pm 2 variables (Shtatland et al., 2001). At each step of the best subsets regression (note: the step number also corresponds to the number of variables entered into the model), the variables in the subset with highest SCORE chi-square values (not shown) were selected as the "best" combination of variables. 
AIC model assessments for the five response variables resulted in models with different numbers of explanatory variables and different amounts of responses based on what was available for the given variables. Goodness-of-fit for these models was assessed using " $\mathrm{c}$ " (the area under the Receiver Operator Characteristic curve) and the Hosmer-Lemeshow (H-L) statistic (Allison, 2012). P-values (deviance) and variance inflation factors for each covariate were used for assessing predictive capacity. While deviance and aggregate options are useful, they do not work when using many explanatory variables, or if some of them are measured on a continuum (Allison, 2012). C-concordance was calculated using the sensitivity (predicting an event correctly) and specificity- (predicting a non-event correctly/everything other than event of interest) expressed as percent of area on graph of all observations, rather than designating one cut point for the significance level of the models under examination. This $\mathrm{c}$ value represents the percent of the time the model was able to correctly sort an event from a non-event correctly. 


\section{Chapter 4: Results}

\section{Response Rate}

The study sample population consisted of 1837 landowners from the Greenbrier River Valley landscape (Greenbrier, Pocahontas, Summers and Monroe County). Seven landowners were considered ineligible because they no longer owned the property selected in the sample. This reduced the sample size to 1830 . One hundred and five questionnaires were considered undeliverable. A total of 609 full or partially completed questionnaires and 203 refusals were received. This resulted in a response rate of $33 \%$ and a cooperation rate of 75\% (RR2, AAPOR 2011).

\section{Demographics and Property Ownership}

Males comprise 79\% percent of respondents. Most respondents (82\%) had incomes over of $\$ 75,000$. Fifty-five percent (55\%) of respondents were age 65 and older and (55\%) reported attending some college or less education. On average, sixty-nine percent (69\%) of the parcels owned by the respondents had a combination of both agriculture and woodlands. Sixty-five percent (65\%) of the respondents had purchased their properties, $58 \%$ of respondents were residents and most (86\%) did not own other properties in another West Virginia county or other state. 


\section{Modeling Conservation Attributes}

The relationship between the response of considering the ecological health of their neighbors' properties when making management decisions (ECOHEALTH) with the explanatory covariates had an AICmin of two covariates (the lowest covariates of all the models). The first covariate to enter the five models (AICmin and AICmin \pm 2 ) was CONSETHIC followed by CONTACT, RESIDENT, AGE, and UNIQUEOWNER. Shown are the probability values for covariates in the respective models (see Table 3).

Table 3: Results of logistic regression model assessment for the attitude of considering the ecological health of neighboring or nearby properties when making decisions concerning their land (ECOHEALTH).

\begin{tabular}{|c|c|c|c|c|c|}
\hline \multirow[b]{2}{*}{ Covariate } & \multicolumn{5}{|c|}{ ————-Number of covariates-———— } \\
\hline & 1 & 2 & 3 & 4 & 5 \\
\hline & & & values -- & & \\
\hline CONSETHIC & $<0.001$ & 0.023 & 0.011 & 0.010 & 0.013 \\
\hline CONTACT & -- & $<0.001$ & $<0.001$ & $<0.001$ & $<0.001$ \\
\hline RESIDENT & -- & -- & 0.321 & 0.327 & 0.351 \\
\hline AGE & -- & -- & -- & 0.026 & 0.023 \\
\hline UNIQUEOWNER & -- & -- & -- & -- & 0.275 \\
\hline \multicolumn{6}{|l|}{ Goodness-of-fit } \\
\hline $\begin{array}{l}\text { H-L Test (p- } \\
\text { value) }\end{array}$ & -- & 0.805 & 0.786 & 0.636 & 0.181 \\
\hline $\begin{array}{l}\text { Area under ROC } \\
\text { curve (c) }\end{array}$ & 0.580 & 0.637 & 0.648 & 0.669 & 0.677 \\
\hline Score Criterion & 11.165 & 16.342 & 18.175 & 19.720 & 21.199 \\
\hline Max rescaled R2 & 0.025 & 0.065 & 0.070 & 0.085 & 0.090 \\
\hline $\begin{array}{l}\text { Deviance (p- } \\
\text { value) }\end{array}$ & -- & 0.510 & 0.536 & 0.676 & 0.0617 \\
\hline $\mathrm{N}$ & 575 & 573 & 566 & 558 & 553 \\
\hline \multicolumn{6}{|l|}{ AIC measures } \\
\hline AIC & 335.919 & 332.046 & 332.074 & 332.378 & 332.810 \\
\hline Delta AIC & 3.873 & 0.000 & 0.028 & 0.332 & 0.764 \\
\hline Akaike weight & 0.039 & 0.273 & 0.269 & 0.231 & 0.186 \\
\hline Evidence ratio & 0.144 & 1.000 & 0.986 & 0.847 & 0.682 \\
\hline
\end{tabular}


The relationship between the response of neighbors talking to (respondents) about their management decisions (MGTDEC) with the explanatory covariates had an AICmin that included four covariates. The first covariate to enter the five models was CONTACT, followed by PLAN, EDUCATION, OWNOTHER, ECONDEP and PROXCITY. Shown are the probability values for covariates in the respective models (Table 4).

Table 4: Results of logistic regression model assessment for the action of neighbors or owners of nearby properties have speaking to respondents about their management decisions (MGTDEC).

\begin{tabular}{|c|c|c|c|c|c|}
\hline \multirow[b]{2}{*}{ Covariate } & \multicolumn{4}{|c|}{-- - - Number of covariates-- - - } & \multirow[b]{2}{*}{6} \\
\hline & 2 & 3 & 4 & 5 & \\
\hline & & 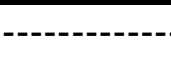 & -values -- & ----------. & ---- \\
\hline CONTACT & 0.008 & 0.040 & 0.099 & 0.131 & 0.124 \\
\hline PLAN & 0.033 & 0.024 & 0.008 & 0.017 & 0.025 \\
\hline EDUCATION & -- & 0.007 & 0.023 & 0.018 & 0.018 \\
\hline OWNOTHER & -- & -- & 0.270 & 0.273 & 0.147 \\
\hline ECONDEP & -- & -- & -- & 0.198 & 0.235 \\
\hline PROXCITY & -- & -- & -- & -- & 0.946 \\
\hline \multicolumn{6}{|l|}{ Goodness-of-fit } \\
\hline $\begin{array}{l}\text { H-L Test (p- } \\
\text { value) }\end{array}$ & 0.611 & 0.746 & 0.964 & 0.716 & 0.662 \\
\hline Area under ROC & & & & & \\
\hline curve (c) & 0.621 & 0.652 & 0.654 & 0.660 & 0.666 \\
\hline Score Criterion & 17.029 & 19.438 & 21.591 & 23.392 & 24.332 \\
\hline Max rescaled R2 & 0.053 & 0.070 & 0.073 & 0.074 & 0.076 \\
\hline $\begin{array}{l}\text { Deviance (p- } \\
\text { value) }\end{array}$ & 0.338 & 0.272 & 0.441 & 0.269 & 0.611 \\
\hline $\mathrm{n} 2$ & 586 & 574 & 535 & 523 & 510 \\
\hline \multicolumn{6}{|l|}{ AIC measures } \\
\hline AIC & 372.614 & 372.131 & 371.739 & 371.823 & 372.556 \\
\hline Delta AIC & 0.875 & 0.392 & 0.000 & 0.084 & 0.817 \\
\hline Akaike weight & 0.158 & 0.201 & 0.244 & 0.234 & 0.162 \\
\hline Evidence ratio & 0.646 & 0.822 & 1.000 & 0.958 & 0.664 \\
\hline
\end{tabular}


The relationship between the response for interest in joint management of wildlife habitat model (HABITAT) model with the covariates had an AICmin of five covariates. The covariates RESIDENT and AGE remained in all five models (AICmin and AICmin \pm 2 ). The covariate EDUCATION entered the first model (three covariates) but was removed in the four and five covariate model, this covariate returned in the six and seven covariate models. TAXTYPE and CONTACT appeared in the models with four through seven covariates. PRODUCTION was included in the models with five through seven covariates and CONSETHIC was the last to enter appearing in only the model with seven covariates. Shown are the probability values for covariates in the respective models (Table 5).

Table 5: Results of logistic regression model assessment for interest in talking with neighbors about managing wildlife habitat together in the future (HABITAT).

\begin{tabular}{lrrrrr}
\hline & \multicolumn{5}{c}{- Number of covariates----二 } \\
Covariate name & 3 & 4 & 5 & 6 & 7 \\
\hline RESIDENT & 0.035 & 0.007 & $<0.001$ & $<0.001$ & 0.002 \\
AGE & 0.001 & $<0.001$ & $<0.001$ & $<0.001$ & $<0.001$ \\
EDUCATION & 0.008 & -- & -- & 0.027 & 0.024 \\
TAXTYPE & -- & 0.055 & 0.002 & 0.005 & 0.003 \\
CONTACT & -- & 0.003 & 0.001 & 0.004 & 0.008 \\
PRODUCTION & -- & -- & 0.021 & 0.027 & 0.018 \\
CONSETHIC & -- & -- & -- & -- & 0.059 \\
Goodness-of-fit & & & & & \\
H-L Test (p-value) & 0.685 & 0.717 & 0.868 & 0.713 & 0.559 \\
Area under ROC & & & & & \\
curve (c) & 0.639 & 0.654 & 0.682 & 0.692 & 0.705 \\
Score Criterion & 32.036 & 35.562 & 39.977 & 41.972 & 43.585 \\
Max rescaled R2 & 0.078 & 0.088 & 0.131 & 0.141 & 0.154 \\
Deviance (p-value) & 0.412 & 0.867 & 0.632 & 0.436 & 0.364 \\
n2 & 551 & 543 & 488 & 484 & 482 \\
AIC measures & & & & & \\
AIC & 480.362 & 478.258 & 475.250 & 475.303 & 475.445 \\
Delta AIC & 5.112 & 3.008 & 0.000 & 0.053 & 0.195 \\
Akaike weight & 0.024 & 0.069 & 0.314 & 0.306 & 0.285 \\
Evidence ratio & 0.077 & 0.222 & 1 & 0.974 & 0.907 \\
\hline
\end{tabular}


The relationship between interest in conservation easement with a group of properties model (CONEASE) model with the covariates in the AICmin had three covariates. The first covariate to enter the group of five models (AICmin and AICmin \pm 2 covariates) was CONSETHIC, followed by EDUCATION, PURCHASE, UNIQUEOWNER and PRODUCTION). Shown are the probability values for covariates in the respective models (Table 6).

Table 6: Results of logistic regression model assessment for interest in working with neighbors to write a conservation easement agreement to protect more than one ownership from development (CONEASE).

\begin{tabular}{|c|c|c|c|c|c|}
\hline \multirow[b]{2}{*}{ Covariate } & \multicolumn{5}{|c|}{-- - - Number of covariates--- - } \\
\hline & 1 & 2 & 3 & 4 & 5 \\
\hline & ------------. & 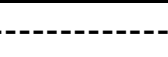 & P-values & & ------- \\
\hline CONSETHIC & $<0.001$ & $<0.001$ & $<0.001$ & $<0.001$ & $<0.001$ \\
\hline EDUCATION & -- & $<0.001$ & $<0.001$ & 0.001 & $<0.001$ \\
\hline PURCHASE & -- & -- & 0.111 & 0.083 & 0.116 \\
\hline UNIQUEOWNER & -- & -- & -- & 0.133 & 0.187 \\
\hline PRODUCTION & -- & -- & -- & -- & 0.187 \\
\hline \multicolumn{6}{|l|}{ Goodness-of-fit } \\
\hline H-L Test (p-value) & -- & 0.555 & 0.441 & 0.506 & 0.832 \\
\hline Area under ROC & & & & & \\
\hline curve (c) & 0.646 & 0.685 & 0.697 & 0.707 & 0.719 \\
\hline Score Criterion & 25.938 & 34.844 & 37.074 & 38.822 & 40.389 \\
\hline Max rescaled R2 & 0.110 & 0.144 & 0.157 & 0.165 & 0.186 \\
\hline Deviance (p-value) & -- & 0.277 & 0.206 & 0.206 & 0.454 \\
\hline $\mathrm{n} 2$ & 365 & 357 & 356 & 354 & 320 \\
\hline \multicolumn{6}{|l|}{ AIC measures } \\
\hline AIC & 328.295 & 320.270 & 319.619 & 319.621 & 319.690 \\
\hline Delta AIC & 8.676 & 0.652 & 0.000 & 0.002 & 0.071 \\
\hline Akaike weight & 0.004 & 0.195 & 0.270 & 0.270 & 0.261 \\
\hline Evidence ratio & 0.013 & 0.722 & 1.000 & 0.999 & 0.965 \\
\hline
\end{tabular}


The relationship between the response for interest in jointly allowing leased access for recreation and hunting (ACCESS) model had an AICmin of five covariates. The first covariate to enter the model was CONSETHIC, followed by ECONDEP, EDUCATION, LNPROXCITY, LEASE, FEMALE, and PLAN. The AICmin and AICmin \pm 2 covariates probability values for covariates are shown in the respective models (Table 7).

Table 7: Results of logistic regression model assessment for Interest in asking neighbors to join a group to lease hunting and recreation access to their shared properties in the future (ACCESS).

\begin{tabular}{lrrrrr}
\hline & \multicolumn{7}{c}{- - Number of covariates-- - - } & \\
Covariate & 3 & 4 & 5 & 6 & 7 \\
\hline CONSETHIC & 0.026 & 0.035 & 0.030 & 0.064 & 0.050 \\
ECONDEP & 0.009 & 0.007 & 0.009 & 0.009 & 0.016 \\
EDUCATION & 0.098 & 0.067 & 0.077 & 0.054 & 0.065 \\
LNPROXCITY & -- & 0.200 & 0.177 & 0.152 & 0.129 \\
LEASE & -- & -- & 0.061 & 0.054 & 0.079 \\
FEMALE & -- & -- & -- & 0.135 & 0.135 \\
PLAN & -- & -- & -- & -- & 0.384 \\
Goodness-of-fit & & & & & \\
H-L Test (p-value) & 0.707 & 0.234 & 0.576 & 0.187 & 0.053 \\
Area under ROC & & & & & \\
curve (c) & 0.575 & 0.591 & 0.598 & 0.599 & 0.603 \\
Score Criterion & 16.216 & 20.716 & 22.678 & 24.395 & 25.754 \\
Max rescaled R2 & 0.027 & 0.034 & 0.042 & 0.048 & 0.048 \\
Deviance (p-value) & 0.435 & 0.002 & 0.002 & $<.001$ & $<.001$ \\
n2 & 550 & 535 & 527 & 524 & 523 \\
AIC measures & & & & & \\
AIC & 518.941 & 515.957 & 515.909 & 515.943 & 516.389 \\
Delta AIC & 3.032 & 0.048 & 0.000 & 0.034 & 0.480 \\
Akaike weight & 0.055 & 0.246 & 0.252 & 0.248 & 0.198 \\
Evidence ratio & 0.219 & 0.976 & 1.000 & 0.983 & 0.786 \\
\hline
\end{tabular}




\section{'Best' Models.}

Overall, the five models for each response variable used a minimum of 2 covariates and a maximum of five covariates. Conservation ethic, contact and education occurred most frequently. Many of the same variables included in the final models, also appeared in the AICmin \pm 2 covariate models such as PRODUCTION in the CONEASE models, ECONDEP in the MGTDEC models, CONSETHIC and PLAN in the HABITAT models. Also not included in the final models the covariate FEMALE enters the six-covariate HABITAT model. Previous research has found that recreational walking was a gender neutral management activity in a comparison of male and female woodland owner preferences (Fegel et al.,2014 ).

The model for ECOHEALTH had a minimum AIC of 332.046 ( $\mathrm{p}$ value $=0.805, \mathrm{c}=0.648$ ) and used 573 observations. The model for MGTDEC had a minimum AIC of 371.739 (p value $=0.964, \mathrm{c}=0.654$ ) and used 535 observations. The model for HABITAT had a minimum AIC of 475.250 ( $p$ value $=0.868, c=0.682$ ) and used 488 observations. The model for CONEASE had a minimum AIC of 319.619 ( $\mathrm{p}$ value $=0.441, \mathrm{c}=0.697$ ) and used 356 observations. The model for ACCESS had a minimum AIC of 515.909 ( $p$ value $=0.576$, $\mathrm{c}=0.598)$ and used 527 observations.

The relationship of the response variable ECOHEALTH and the variables of interest showed that landowners who have contacted a professional forester or agriculture professional have 2.6 times the odds of considering the ecological health of their neighbors or nearby properties when making management decisions on their property. Respondents who felt a higher level of attachment and commitment to their property CONSETHIC had 67\% greater odds of considering the health of their neighboring the odds. 
Respondents with neighbors or owners of nearby properties that haven spoken to them about their management decisions (MGTDEC) were positively affected by PLAN (1.23 times the odds), EDUCATION (1.7 times the odds), and CONTACT (1.54 times the odds). Of the respondent's landowners that own other property in another West Virginia County or state (OWNOTHER) had 33\% less odds of reporting that their neighbors speak to them about their management decisions (Table 8). VIF is variance inflation factor to assess multicollinearity and was computed using PROC REG following model building.

Table 8: "Best" models assessment of strength of covariate relationships with dichotomous response variables do you consider the ecological health of neighboring or nearby properties when making decisions concerning their land (ECOHEALTH) and Neighbors or owners of nearby properties have spoken to you about their management decisions (MGTDEC).

\begin{tabular}{rccrrr}
\hline \multicolumn{1}{l}{ Covariate } & Odds Ratio & $----95 \%$ Confidence Limits---- & p >chisq & VIF \\
\hline CONTACT & 2.602 & 1.536 & 4.408 & $<0.001$ & 1.022 \\
CONSETHIC & 1.672 & 1.075 & 2.600 & 0.023 & 1.022 \\
& \multicolumn{7}{c}{ ECOHEALTH } \\
PLAN & 2.291 & 1.232 & 4.259 & 0.008 & 1.252 \\
EDUCATION & 1.709 & 1.075 & 2.717 & 0.024 & 1.011 \\
CONTACT & 1.543 & 0.922 & 2.584 & 0.099 & 1.263 \\
OWNOTHER & 0.667 & 0.325 & 1.370 & 0.270 & 1.002 \\
\hline
\end{tabular}


Similarly, CONTACT is an important variable for respondent's future interested in talking with their neighbors about managing wildlife habitat together (HABITAT) (odds 2.78). Reasons to own for production from farm or forest (WTL) had interactions in the model (1.73 times the odds) but were not significant. Residency (RESIDENT), enrollment in farmland or managed timberland taxation programs (TAXTYPE), and age over 65 (AGE) had a negative effect on the odds of considering joint habitat management. RESIDENT and TAXTYPE had 50\% less the odds and AGE 45\% less the odds of taking with their neighbors about joint wildlife habitat management.

The cooperative activity of asking neighbors about joining a group to allow leased hunting and recreational access on shared properties (ACCESS) was positively influenced by ECONDEP. Respondents that identified with the sense of place attribute ECONDEP had 1.6 times the odds of agreement, while respondent's that identified with the other sense of place attribute CONSETHIC had .67 times the odds. While not significant, there was model interaction with landowners that already lease properties (LEASE 1.508 times the odds), had at least a college degree (EDUC 1.4 times the odds) and lived closer to a town (LNPROXCITY 1.1 times the odds).

In the logistic model for the cooperative activity CONEASE, respondents who identified with the sense of place attributes of CONSETHIC had 3.45 times the odds of being interested in working with their neighbors to protect more than one ownership with a conservation easement. Respondents having a college degree or above (EDUC) had 2.22 times the odds and those that purchased their property (PURCHASE) had 1.45 times the odds of agreement on the CONEASE future cooperative activity (Table 9). 
Table 9: "Best" model assessment of strength of covariate relationships with dichotomous response variables) Interested in talking with neighbors about managing wildlife habitat together in the future (HABITAT), Interested in asking neighbors to join a group to lease hunting and recreation access to their shared properties in the future (ACCESS), and Interested in working with neighbors to write a conservation easement agreement to protect more than one ownership from development (CONEASE).

\begin{tabular}{|c|c|c|c|c|c|}
\hline Covariate & Odds Ratio & \multicolumn{2}{|c|}{----95\% Confidence Limits---- } & $\mathrm{p}>$ chisq & VIF \\
\hline \multicolumn{6}{|c|}{ HABITAT } \\
\hline CONTACT & 2.788 & 1.372 & 3.367 & $<0.001$ & 1.149 \\
\hline PRODUCTION & 1.739 & 1.085 & 2.788 & 0.022 & 1.109 \\
\hline RESIDENT & 0.503 & 0.333 & 0.759 & 0.001 & 1.063 \\
\hline TAXTYPE & 0.502 & 0.326 & 0.773 & 0.002 & 1.215 \\
\hline AGE & 0.447 & 0.300 & 0.666 & $<0.001$ & 1.004 \\
\hline \multicolumn{6}{|c|}{ ACCESS } \\
\hline ECONDEP & 1.637 & 1.128 & 2.374 & 0.009 & 1.093 \\
\hline LEASE & 1.508 & 0.981 & 2.320 & 0.061 & 1.016 \\
\hline EDUCATION & 1.389 & 0.964 & 2.003 & 0.077 & 1.054 \\
\hline LNPROXCITY & 1.110 & 0.954 & 1.292 & 0.177 & 1.008 \\
\hline CONSETHIC & 0.667 & 0.463 & 0.962 & 0.030 & 1.053 \\
\hline \multicolumn{6}{|c|}{ CONEASE } \\
\hline CONSETHIC & 3.486 & 2.216 & 5.484 & $<0.001$ & 1.051 \\
\hline EDUCATION & 2.216 & 1.417 & 3.467 & $<0.001$ & 1.018 \\
\hline PURCHASE & 1.464 & 0.917 & 2.338 & 0.111 & 1.034 \\
\hline
\end{tabular}




\section{Chapter 5: Discussion}

Cross-boundary conservation attributes were identified amongst landowners in the Greenbrier River Valley landscape. This study aimed to understand the relationships between landowner attributes, land management activities, sense of place, and willingness to participate in cross-boundary conservation efforts.

Following Rickenbach, Bliss, and Reed's (2004) recommendations to pay close attention to the ownership patterns and the motivations and intentions that guide the land use, felt sense of place, conservation interests, demographics and history of the Greenbrier River Valley in southeastern West Virginia were collected. Part of this information was captured using a sense of place scale developed by Cross et al. (2011).

As demonstrated by our SOP analysis, many landowners in the study area exhibit an ideological place attachment, an affinity to the land and felt responsibility for place as well as a distinct place dependence related to the economic dependence and reliance on the land. High conservation ethic positively influenced landowners' attitude toward considering neighboring properties in their management decisions and their interest in future collaboration with other property owners on conservation easements. This finding is similar to that of Finley et al. (2006), where they found one segment of landowners to be conservation cooperators - those primarily interested in cooperative activities that promote conservation ideals such as writing a collective conservation easement. Finley et al. (2006) found conservation cooperators to consider the ecological health of neighboring properties and that they held high values of environmental stewardship, enjoyed working on their property and owning it for its environmental values. 
Conservation ethic had a negative influence on a landowner's interest in allowing leased hunting or recreation access with joint properties. This suggests that the affinity to and responsibility felt by landowners may be intertwined with a level of control in management decisions, or protectiveness. As found in the Wild and Scenic River Environmental Assessment for the Greenbrier River landowners are wary of losing their rights from eminent domain. This is similar to findings by Burton (2004) and Leopold (1939) where farmers expressed feeling responsible for the construction of the landscape and the fact that their farm is more than a landscape, but rather is an image of the farmer themselves. Farmers often attach their identity to farming, working the land and following particular set of norms that could be changed by policies and educational initiatives. Their identity is tied to a strong stewardship ethic (Burton, 2004).

For the sense of place analysis this study focused on landowners' properties rather than the landscape as a whole. Since "people have relationships to places as small as a favorite rock next to the river and as large as a geographical regions" (Cross et al., 2006, p. 5) it may be beneficial to identify and examine differences in relationship to place from the landowner's parcel level and the surrounding landscape as a whole. For example the term community in "I manage my land to maximize benefit to my community" could be replaced with Greenbrier River Valley Landscape, "I manage my land to maximize benefit the Greenbrier River Valley". Since we did not specify the name of the community in the questionnaire items, several communities within the study area may have been represented, not necessarily the Greenbrier River Valley Landscape. Similarly the closest town could have been specified to understand associations with larger city/smaller 
community influences, for example "My property is miles from Lewisburg" or "My

property is ___ miles from Washington, $\mathrm{DC}^{\prime \prime}$. Another option would be to ask landowners to identify their definition of landscape (Erazo, 2014).

\section{Implications for Managing Farmlands and Woodlands}

Farmers and ranchers (landowners whose livelihood was directly dependent on resource exploitation) may have a strong negative attitude toward conservation (Langpap, 2004; Ma et al., 2010). As part of our sense of place scale, economic dependence identifies 'My future livelihood depends on having flexible land use.' This indicates that landowners may be concerned with the flexibility of the cross-boundary projects and the effect on their income earning potential. Economic dependence was positively associated with landowner's interest in allowing recreational or hunting access on their properties, indicating they foresee the financial gain from these types of endeavors. This result is similar to efforts with public and private forest managers in Oregon's John Day Valley, where the valley's economy is heavily dependent on cattle, timber, and recreational hunting. (Bergmann \& Bliss, 2004) found the role of private land ownership in landowner identity and independence to be significant in their interest in cooperative fire management. 
Since landowners who already lease their land were interested in cross-boundary leasing for recreation and hunting access, they may already accrue benefits in leasing or may see the cooperative activity of leasing for access to be less of a change from their present practices. Future research might examine the effects of specific management activities on sense of place such as leasing land, and allowing access for recreation separate from hunting. Additionally, tenure may be important to incorporate as sense of place can change throughout time (Cross et al., 2006).

Landowner's who purchased their properties had positive interest in participation in conservation easements. Non-inheritors place significantly more importance than multigenerational woodland owners on the following motivations for owning their woodland for privacy, as part of their home, esthetics, protection of biodiversity, and for recreation other than hunting or fishing (Majumdar et al., 2009).

The opportunity to pass on land as legacy for their heirs may seem threatened by respondent's understanding of conservation easements. Inheritors are much more likely than first-generation woodland owners to be motivated by the opportunity of passing along a legacy of woodland to their children or heirs (Majumdar et al., 2009; Conway et al., 2003. If groups are interested in targeting this audience they may consider the effect of conservation projects for future generations and provide better resources for landowner's to understand the risks and benefits related to the effect of conservation easements on transferring properties, another existing action that may not be perceived as an extreme change to existing practices. 
Agriculture acreage owned and forest acreage owned were not significant in the models of cross-boundary interest and interaction. Haymond (1988) made distinctions between farm and non-farm owners where farmers were more interested in economics and timber production and non-farmers were more interested in the lifestyle enhancement value. Though it was expected, farm was not a variable providing interaction in our model, however interaction from other variables such as PRODUCTION may have influenced this.

Capturing a productive aspect of land management, the managed timberland and farmland tax programs were included in the habitat model but provided a negative association with interest in wildlife habitat with nearby properties or neighbors (HABITAT). This reveals that enrollment in production-based tax programs is not necessarily a predictor of landowner's interest in both cross-boundary efforts and specifically managing wildlife habitat together.

Agriculture acreage owned was not significant in the selected models. Ownership for PRODUCTION from farm or forest was significant in a positive relationship to landowner interest in jointly managing wildlife habitat with neighbors and may have captured some of the variance explained by farm designation or agriculture acreage. Because of the variables (PRODUCTION and TAXTYPE) included in the model this could be related landowner's issues with deer eating crops or gardens in the HABITAT model. Residents were also less interested talking with neighbors regarding joint management of wildlife habitat. Older landowners had a negative association with interest in talking with neighbors about managing wildlife, this could be caused by a perceived inability to undertake projects in habitat management because of their age. 
Of the respondents 131 were sole woodland owners and 56 were sole agriculture owners, and 423 owned combined agriculture and woodland properties. This distribution may have limited the interaction of this variable in the models. Agriculture acreage and woodland acreage were not significant in the models. A post-hoc Chi-square test of independence revealed that the agriculture ownership attribute was significant ECOHEALTH $(\mathrm{P}=0.033$, $\left.\chi^{2}=4.546\right)$. Agriculture landowners had 0.63 times the odds of considering their neighbors or nearby properties when making management decisions than sole woodland owners. Landowner's having a combination of agriculture land and woodland had 1.3 times the odds of saying they consider their neighbors or nearby properties when making management decisions $\left(\mathrm{P}=0.018, \chi^{2}=5.538\right)$.

Neither land cover type nor parcel size were statistically important in this modeling effort. Hence, targeting a particular size of parcel or percent of forestland may not be a useful filter for targeting landowners that may be willing to participate in cross-boundary projects when using the WV tax database. Future work interested in the differences between these groups interested in a farm variable could direct mailings to farms using lists from state or USDA reported farm designations, to include a larger sample of farms. 


\section{Implications for Outreach and Education}

The variable CONTACT where landowners had either contacted a professional forester or agriculture professional positively contributed to the models for three of the five cooperative attitudes, actions and activities (ECOHEALTH, MGTDEC, and HABITAT). This supports results similar to Cross et al. (2011) indicating that efforts by professionals and connections through outreach and education may be worthwhile in future projects supporting landscape scale habitat management and encouraging landowners to consider and talk to neighbors when making management decisions. Also, landowners who had a farm or forest management plan said their neighbors talked to them about their management decisions.

Conservation efforts and the benefits that they accrue can only be effective in the long term through the support of the farming community in agricultural areas (Burton, 2004). Support could be gained through professionals making initial contact with landowners, designing cross-boundary projects that in some way mirror existing projects to minimize perceived change (leasing). 
While it is useful to categorize landowners to attempt to focus outreach and education efforts it may be useful as well to find the common ties between groups of landowners that can bring them together to achieve landscape level management success. New opportunities for landscape-scale environmental management may emerge by considering landowners' intentions in managing forests and agricultural lands, together on a landscape level. Using sense of place as a tool, while conflicting perceptions may arise, can be the common ground based on experience and connection with an area. For example exploring the conservation actions and affinities of landowners, specifically for a project like oil and gas development, to identify and understanding associations between the diversity of their attitudes and interests in conservation related to a specific project could prove beneficial in a statewide project.

Conservation ethics have a positive and negative relationship to landowners' interest in cross-boundary participation. Some landowners may hold a strong personal commitment to the stewardship of a property, but the property may be such a strong part of their selfidentity and workplace that it conflicts with their interest in cross-boundary conservation. This may be due to fear of loss of privacy (Fischer \& Charnley, 2012) because it requires a landowner to release some control of the land (McGill et al., 2008; Fischer \& Bliss, 2008) or they anticipate loss of identity though change in management (Burton, 2004). 
Cross et al. (2011) found economic dependence had a negative relationship with landowners' trust of conservation easements. However, economic dependence may not limit participation; in fact it can increase interest, as seen in the future cooperative activity of leasing for access. Conservation ethic should not be assumed to result in the support of a conservation program, policy or other initiative (Cross et al., 2011) and economic dependence should not always be seen as a barrier. 


\section{Literature Cited}

AAPOR. (2011). Standard Definitions: Final Dispositions of Case Codes and Outcome Rates for Surveys. 7th edition. The American Association for Public Opinion Research.

Alig, R. J., Kline, J. D., \& Lichtenstein, M. (2004). Urbanization on the US landscape: looking ahead in the 21st century. Landscape and Urban Planning, 69(2), 219-234.

Allison, L. (1996). On planning a forest: theoretical issues and practical problems. Town Planning Review, 67(2), 131.

Allison, P. D. (2012). Logistic regression using SAS: Theory and application. SAS Institute.

Alverson, W. S. (1994). Wild forests: conservation biology and public policy. Island Press.

Barnes, K. B., Morgan III, J. M., Roberge, M. C., \& Lowe, S. (2001). Sprawl development: its patterns, consequences, and measurement. Towson University, Towson, 1-24.

Batie, S. S. (2001). Public Programs and Conservation on Private Lands.

Baylis, K., Peplow, S., Rausser, G., \& Simon, L. (2008). Agri-environmental policies in the EU and United States: A comparison. Ecological Economics, 65(4), 753-764.

Bengtsson, J., Angelstam, P., Elmqvist, T., Emanuelsson, U., Folke, C., Ihse, M., ... \& Nyström, M. (2003). Reserves, resilience and dynamic landscapes. AMBIO: A Journal of the Human Environment, 32(6), 389-396.

Bergmann, S. A., \& Bliss, J. C. (2004). Foundations of cross-boundary cooperation: resource management at the public-private interface. Society \& Natural Resources, 17(5), 377-393.

Best, C., \& Wayburn, L. A. (2001). America's private forests: status and stewardship. Island Press.

Bliss, J. C., \& Martin, A. J. (1989). Identifying NIPF management motivations with qualitative methods. Forest Science, 35(2), 601-622.

Boyer, D. G. (2005). Water Quality Improvement Program Effectiveness For Carbonate Aquifers In Grazed Land Watersheds1.

Bromley, D. W. (1991). Environment and Economy: Property rights and public policy. Oxford,UK: Blackwell.

Brook, A., Zint, M., \& De Young, R. (2003). Landowners' responses to an Endangered Species Act listing and implications for encouraging conservation. Conservation Biology, 17(6), 1638-1649. 
Budget Travel, 2011. September. Hometown Escapes: 10 Coolest Small Towns in America 2011. Retrieved from http://www.budgettravel.com/feature/10-coolest-smalltowns-in-america-2011. Feb 12, 2015)

Burton, R. J. (2004). Seeing through the 'good farmer's' eyes: towards developing an understanding of the social symbolic value of 'productivist' behaviour. Sociologia Ruralis, 44(2), 195-215.

Busck, A. G. (2002). Farmers' landscape decisions: relationships between farmers' values and landscape practices. Sociologia Ruralis, 42(3), 233-249.

Butler, B. J. (2008). Family forest owners of the United States, 2006. Gen. Tech. Rep. NRS27. Newtown Square, PA: US Department of Agriculture, Forest Service, Northern Research Station, 73.

Butler, B. J., \& Leatherberry, E. C. (2004). America's family forest owners. Journal of Forestry, 102(7), 4-14.

Butler, B. J., \& Ma, Z. (2011). Family forest owner trends in the Northern United States. Northern Journal of Applied Forestry, 28(1), 13-18.

Butler, B. J., Leatherberry, E. C., \& Williams, M. S. (2005). Design, implementation, and analysis methods for the National Woodland Owner Survey.

Cheng, A. S., Kruger, L. E., \& Daniels, S. E. (2003). " Place" as an Integrating Concept in Natural Resource Politics: Propositions for a Social Science Research Agenda. Society \& Natural Resources, 16(2), 87-104.

Clark, C. (2014, October, 6). Greenbrier River group to hold pipeline meetings. WVVA Television, Retrieved from http://www.wvva.com/story/26835504/2014/10/20/greenbrier-river-groupto-hold-pipeline-meetings

Colyer, D. (1978). Socio-Economic Determinants of Rural Land Values in Greenbrier County, West Virginia. Journal of the Northeastern Agricultural Economics Council, 7, 75-77.

Colyer, D. (1998). Farmland preservation programs. Paper presented at the Seventh International Symposium on Society and Resource Management, University of Missouri, Columbia, May 25-27, 1998.

Conner, M., \& Armitage, C. J. (1998). Extending the theory of planned behavior: A review and avenues for further research. Journal of Applied Social Psychology, 28(15), 1429-1464. 
Constantz, G. (2000). Grassroots-based watershed conservation in central Appalachia. Mountain Research and Development, 20(2), 122-125.

Craig, W. (n.d.).The Voluntary Farmland Protection Act-County farmland protection program. Retrieved from:

http://www.ext.wvu.edu/jefferson/WV_farmland_protection/Fact_Sheets/Farml and\%20Protection\%20County.dochttp://www.ext.wvu.edu/jefferson/WV_farml and_protection/Fact_Sheets/Farmland\%20Protection\%20County.doc. Retrieved February 15, 2015.

Cross, J. E. (2001). Private property rights versus scenic views: A battle over place attachments. In 12th Headwaters Conference, Western State College.

Cross, J. E., Keske, C. M., Lacy, M. G., Hoag, D. L., \& Bastian, C. T. (2011). Adoption of conservation easements among agricultural landowners in Colorado and Wyoming: The role of economic dependence and sense of place. Landscape and Urban Planning, 101(1), 75-83.

Davenport, M. A., \& Anderson, D. H. (2005). Getting from sense of place to place-based management: An interpretive investigation of place meanings and perceptions of landscape change. Society and Natural Resources, 18(7), 625-641.

Davenport, M. A., \& Anderson, D. H. (2005). Getting from sense of place to place-based management: An interpretive investigation of place meanings and perceptions of landscape change. Society and Natural Resources, 18(7), 625-641.

De Groot, R. S., Alkemade, R., Braat, L., Hein, L., \& Willemen, L. (2010). Challenges in integrating the concept of ecosystem services and values in landscape planning, management and decision making. Ecological Complexity, 7(3), 260-272.

Dillman, D. A. (1978). Mail and telephone surveys (Vol. 3). Wiley Interscience.

Dillman, D. A. (2000). Mail and Internet surveys--The tailored design method. New York : John Wiley \& Sons, Inc.

Dodson, C. B. (2004). Farmland Ownership Transitions. Journal of the American Society of Farm Managers and Rural Appraisers, 67(1), 19-26.

Dunn, C. P., Stearns, F., Guntenspergen, G. R., \& Sharpe, D. M. (1993). Ecological benefits of the conservation reserve program. Conservation Biology, 7(1), 132-139.

Dwyer, J. F., \& Childs, G. M. (2004). Movement of people across the landscape: a blurring of distinctions between areas, interests, and issues affecting natural resource management. Landscape and Urban Planning, 69(2), 153-164. 
Egan, A. F. (1997). From timber to forests and people: a view of nonindustrial private forest research. Northern Journal of Applied Forestry, 14(4), 189-193.

Egan, A. F., \& Luloff, A. E. (2000). The exurbanization of America's forests: Research in rural social science. Journal of Forestry, 98(3), 26-30.

EIS (1984). Greenbrier wild \& scenic river study : Final environmental impact statement and study report. United States:

www.usda.gov/documents/FORESTRY_TITLE.pdf

Erickson, D. L., Ryan, R. L., \& De Young, R. (2002). Woodlots in the rural landscape: landowner motivations and management attitudes in a Michigan (USA) case study. Landscape and Urban Planning, 58(2), 101-112.

Finely, A. O., Kittredge, D. B., Stevens, T. H., Schweik, C. M., \& Dennis, D. C. (2006). Interest in cross-boundary cooperation: identification of distinct types of private forest owners. Forest Science, 52(1), 10-22.

Fischer, A. P., \& Bliss, J. C. (2008). Behavioral Assumptions of Conservation Policy: Conserving Oak Habitat on Family-Forest Land in the Willamette Valley, Oregon. Conservation Biology, 22(2), 275-283.

Fischer, A. P., \& Charnley, S. (2012). Private forest owners and invasive plants: risk perception and management. Invasive Plant Science and Management, 5(3), 375389.

Fischer, A. P., \& Charnley, S. (2012). Risk and cooperation: managing hazardous fuel in mixed ownership landscapes. Environmental management, 49(6), 1192-1207.

Fisher, S. L., \& Smith, B. E. (Eds.). (2012). Transforming Places: Lessons from Appalachia. Baltimore, MD, USA: University of Illinois Press. Retrieved from http://www.ebrary.com

Freyfogle, E. T. (1998). Owning the land: Four contemporary narratives. J. Land Use Environ.Law13:279-307.

George, D., \& Mallery, P. (2003). SPSS for Windows step by step: A simple guide and reference. 11.0 update (4th ed.). Boston: Allyn \& Bacon.

Goldman, R. L., Thompson, B. H., \& Daily, G. C. (2007). Institutional incentives for managing the landscape: Inducing cooperation for the production of ecosystem services. Ecological Economics, 64(2), 333-343.

Gorte, R. W., Vincent, C. H., Hanson, L. A., \& Rosenblum, M. R. (2012). Federal land ownership: overview and data. Congressional Research Service, Report, (R42346), 24. 
Gosling, E., \& Williams, K. J. (2010). Connectedness to nature, place attachment and conservation behaviour: Testing connectedness theory among farmers. Journal of Environmental Psychology, 30(3), 298-304.

Gosnell, H., Haggerty, J. H., \& Travis, W. R. (2006). Ranchland ownership change in the Greater Yellowstone Ecosystem, 1990-2001: implications for conservation. Society and Natural Resources, 19(8), 743-758.

Graham, D. L. (1994). Cooperative extension system. Encyclopedia of agricultural science, 1(1994), 415-430.

Groot, J. C., Rossing, W. A., Jellema, A., Stobbelaar, D. J., Renting, H., \& Van Ittersum, M. K. (2007). Exploring multi-scale trade-offs between nature conservation, agricultural profits and landscape quality - a methodology to support discussions on land-use perspectives. Agriculture, Ecosystems \& Environment, 120(1), 58-69.

Harrison, S., Herbohn, J., \& Niskanen, A. (2002). Non-industrial, smallholder, small-scale and family forestry: What's in a name?. Small-Scale Forestry, 1(1), 1-11.

Hart, J. F. (1968). Loss And Abandonment Of Cleared Farm Land In The Eastern United States1. Annals Of The Association Of American Geographers, 58(3), 417-440.

Higgins, A., Serbesoff-King, K., King, M., \& O'Reilly-Doyle, K. (2007). The power of partnerships: landscape scale conservation through public/private collaboration. Natural Areas Journal, 27(3), 236-250.

Hodgdon, B., \& Tyrrell, M. (2003). Literature review: an annotated bibliography on family forest owners. GISF Research paper, 2.

Hoppe, R., \& Weibe, K. (2006). Land ownership and farm structure: 2006 Edition. Agricultural Resources and Environmental Indicators.

Hsieh, H. F., \& Shannon, S. E. (2005). Three approaches to qualitative content analysis. Qualitative Health Research, 15(9), 1277-1288.

Hyman, J. B., \& Leibowitz, S. G. (2000). A general framework for prioritizing land units for ecological protection and restoration. Environmental Management, 25(1), 23-35.

Jackson, J. B. (1980). The necessity for ruins, and other topics. Univ of Massachusetts Press.

Jennings, B. M., \& McGill, D. W. (2005). Evaluating the effectiveness of the Forest Stewardship Program in West Virginia: Ten-year assessment. Northern Journal of Applied Forestry, 22(4), 236-242. 
Joshi, S., \& Arano, K. G. (2009). Determinants of private forest management decisions: a study on West Virginia NIPF landowners. Forest Policy and Economics, 11(2), 118-125.

Kareiva, P., Watts, S., McDonald, R., \& Boucher, T. (2007). Domesticated nature: shaping landscapes and ecosystems for human welfare. Science, 316(5833), 1866-1869.

Kargbo, D. M., Wilhelm, R. G., \& Campbell, D. J. (2010). Natural gas plays in the Marcellus shale: Challenges and potential opportunities. Environmental Science \& Technology, 44(15), 5679-5684.

Karppinen, H. (1998). Values and objectives of non-industrial private forest owners in Finland. Silva fennica, 32, 43-59.

Kay, David, \& Nelson Bills., (2007). Owners of Idle Agricultural and Forest Land in New York State: Results from a Mail Survey. CaRDI Reports. Issue Number 1

Kittredge, D.B. (2004). Extension/outreach implications for America's family forest owners. Journal of Forestry, 102(7):15-18. 4.

Knight, R. L., \& Landres, P. (Eds.). (2013). Stewardship across boundaries. Island Press.

Koontz, T. M. (2001). Money talks? But to whom? Financial versus nonmonetary motivations in land use decisions. Society \& Natural Resources, 14(1), 51-65.

Krejcie, R. V., \& Morgan, D. W. (1960). Small-sample techniques. The NEA Research Bulletin, 38, 99.

Kuhns, M. R., Brunson, M. W., \& Roberts, S. D. (1998). Landowners' educational needs and how foresters can respond. Journal of Forestry, 96(8), 38-43.

Kvarda, M. E. (2004). 'Non-agricultural forest owners' in Austria-a new type of forest ownership. Forest Policy and Economics, 6(5), 459-467.

Laband, D. N., \& Lentz, B. F. (1983). Occupational inheritance in agriculture. American Journal of Agricultural Economics, 65(2), 311-314.

Langpap, C. (2004). Conservation incentives programs for endangered species: An analysis of landowner participation. Land Economics, 80(3), 375-388. doi:10.3368/le.80.3.375

Larson, K. (2004). Family forests--the bigger picture. Journal of Forestry.

Leopold, A. (1939) The farmer as conservationist. American Forests 45 pp. 296-297

Lewis, R. L. (1993). Appalachian restructuring in historical perspective: coal, culture and social change in West Virginia. Urban Studies, 30(2), 299-308. 
Lindner, J. R., Murphy, T. H., \& Briers, G. E. (2001). Handling nonresponse in social science research. Journal of Agricultural Education, 42(4), 43-53

Lichter, D. T. (2005). Emerging patterns of population redistribution and migration in Appalachia. Appalachian Regional Commission.

Likert, R., 1932. A technique for the measurement of attitude. Arch. Psychol., 140.

Loreau, M., Mouquet, N., \& Gonzalez, A. (2003). Biodiversity as spatial insurance in heterogeneous landscapes. Proceedings of the National Academy of Sciences, 100(22), 12765-12770.

M.E, Assessment. (2005). Ecosystems and human well-being: current state and trends.

Ma, Z., Butler, B. J., Kittredge, D. B., \& Catanzaro, P. (2012). Factors associated with landowner involvement in forest conservation programs in the US: Implications for policy design and outreach. Land Use Policy, 29(1), 53-61.

Machlis, G. E., Force, J. E., \& Burch Jr, W. R. (1997). The human ecosystem part I: the human ecosystem as an organizing concept in ecosystem management. Society \& Natural Resources, 10(4), 347-367.

Majumdar, I., Laband, D., Teeter, L., \& Butler, B. (2009). Motivations and land-use intentions of nonindustrial private forest landowners: Comparing inheritors to noninheritors. Forest Science, 55(5), 423-432.

Marcouiller, D. W., Clendenning, J. G., \& Kedzior, R. (2002). Natural amenity-led development and rural planning. Journal of Planning Literature, 16(4), 515-542.

Matson, P. A., Parton, W. J., Power, A. G., \& Swift, M. J. (1997). Agricultural intensification and ecosystem properties. Science, 277(5325), 504-509.

McGill, D. W., Grushecky, S. T., Moss, S., Pierskalla, C., \& Schuler, A. (2008). Landowner willingness to engage in long-term timber leases in West Virginia, USA. Small-scale Forestry, 7(2), 105-116.

Mazerolle, M. J., Bailey, L. L., Kendall, W. L., Andrew Royle, J., Converse, S. J., \& Nichols, J. D. (2007). Making great leaps forward: accounting for detectability in herpetological field studies. Journal of Herpetology, 41(4), 672-689.

McCuen, M. and D. W. McGill (2012). To what extent are woodland neighbors talking? An assessment of interactions between adjacent woodland owners. 18th Central Hardwood Forest Conference.

Mehmood, S. R., \& Zhang, D. (2001). Forest parcelization in the United States: a study of contributing factors. Journal of Forestry, 99(4), 30-34. 
Miles, M. B., \& Huberman, A. M. (1994). Qualitative data analysis: An expanded sourcebook. Sage.

National Park Service. (2005). National Register Information System (NRIS). Retrieved February 22, 2015, from http://www.cr.nps.gov/nr/about.htm

Naveh, Z. (1998). Ecological and Cultural Landscape Restoration and the Cultural Evolution towards a Post-Industrial Symbiosis between Human Society and Nature. Restoration Ecology, 6(2), 135-143.

Noble, I. R., \& Dirzo, R. (1997). Forests as human-dominated ecosystems. Science, 277(5325), 522-525.

Pimentel, D., Stachow, U., Takacs, D. A., Brubaker, H. W., Dumas, A. R., Meaney, J. J., ... \& Corzilius, D. B. (1992). Conserving biological diversity in agricultural/forestry systems. BioScience, 354-362.

Pirot, J. Y., Meynell, P. J., \& Elder, D. (Eds.). (2000). Ecosystem management: lessons from around the world: a guide for development and conservation practitioners. IUCN.

Preston, J. F. (1948). Building a Farm Forestry Clientele. Journal of Forestry, 46(5), 371374.

Primdahl, J. (1999). Agricultural landscapes as places of production and for living in owner's versus producer's decision making and the implications for planning. Landscape and Urban Planning, 46(1), 143-150.

Primdahl, J., \& Kristensen, L. S. (2011). The farmer as a landscape manager: Management roles and change patterns in a Danish region. Geografisk Tidsskrift-Danish Journal of Geography, 111(2), 107-116.

Rice, O. K., \& Brown, S. W. (2010). West Virginia: A history. University Press of Kentucky.

Rickenbach, M. G., \& Reed, A. S. (2002). Cross-boundary cooperation in a watershed context: the sentiments of private forest landowners. Environmental Management, 30(4), 584-594.

Rickenbach, M. G., Bliss, J. C., \& Reed, A. S. (2004). Collaboratives, cooperation, and private forest ownership patterns: Implications for voluntary protection of biological diversity. Small-scale Forest Economics, Management and Policy, 3(1), 69-83.

Rickenbach, M., Schulte, L. A., Kittredge, D. B., Labich, W. G., \& Shinneman, D. J. (2011). Cross-boundary cooperation: A mechanism for sustaining ecosystem services from private lands. Journal of Soil and Water Conservation, 66(4), 91A-96A. 
Ryan, R. L., Erickson, D. L., \& De Young, R. (2003). Farmers' motivations for adopting conservation practices along riparian zones in a mid-western agricultural watershed. Journal of Environmental Planning and Management, 46(1), 19-37.

Sagor, E. S. (2012). Personal Networks And Private Forestry: Exploring Extension's Role In Landowner Education (Doctoral Dissertation, University of Minnesota).

Sampson, N., \& DeCoster, L. (2000). Forest fragmentation: implications for sustainable private forests. Journal of Forestry, 98(3), 4-8.

SAS Instrument.(2000). SAS 9.1.3 Help and Documentation, Cary, NC:SAS Institute.20002004.

Scherr, S. J., \& McNeely, J. A. (2008). Biodiversity conservation and agricultural sustainability: towards a new paradigm of 'ecoagriculture'landscapes.

Philosophical Transactions of the Royal Society B: Biological Sciences, 363(1491), 477-494.

Shi, Y. J., Phipps, T. T., \& Colyer, D. (1997). Agricultural land values under urbanizing influences. Land Economics, 90-100.

Shtatland, E. S., Cain, E., \& Barton, M. B. (2001, April). The perils of stepwise logistic regression and how to escape them using information criteria and the output delivery system. In 26th Annual SAS Users Group International Conference, Long Beach, California.

Starr, S. E., \& McConnell, T. E. (2014). Changes in Ohio Tree Farmers' Forest Management Strategies and Outreach Needs. Forest Science, 60(4), 811-816.

Stedman, R. C. (2002). Toward a social psychology of place predicting behavior from place-based cognitions, attitude, and identity. Environment and Behavior, 34(5), 561-581.

Stern, S. (2006). Encouraging conservation on private lands: A behavioral analysis of financial incentives. Ariz. L. Rev., 48, 541.

Thomas, D. R. (2006). A general inductive approach for analyzing qualitative evaluation data. American Journal of Evaluation, 27(2), 237-246.

Tscharntke, T., Klein, A. M., Kruess, A., Steffan-Dewenter, I., \& Thies, C. (2005). Landscape perspectives on agricultural intensification and biodiversity-ecosystem service management. Ecology Letters, 8(8), 857-874.

Turner, M. G., Pearson, S. M., Bolstad, P., \& Wear, D. N. (2003). Effects of land-cover change on spatial pattern of forest communities in the Southern Appalachian Mountains (USA). Landscape Ecology, 18(5), 449-464. 
U. S. Census Bureau. (2013). County Quick Facts Beta: W.V. Retrieved January 18, 2015, from http://www.census.gov/quickfacts/table/PST045213/54,54075,54063,54025,5 4089

U.S. Census Bureau. (2014). State and County QuickFacts. West Virginia. Retrieved September 28, 2014 from http://quickfacts.census.govUSDA, E. A. (2000). Agricultural resources and environmental indicators. Agricultural handbook, 705, July 08.

U.S. Department of Agriculture, National Agricultural Statistics Service (NASS). (2012) 2012 Census of Agriculture Vol. 1: Part 51, Chapter 1, AC-07-A-51, United States Summary and State Data. West Virginia.

USDA Forestry Title (n.d) Farm Bill Forum Comment and Summary Background. USDA United States Department of Agriculture. Retrieved February 18, 2014. From: www.nrcs.usda.gov/Internet/FSE_DOCUMENTS/nrcs142p2

Vilsack T (2009) Agriculture Secretary Vilsack Presents National Vision for America's Forests; Release No.0382.09.http://www.usda.gov. November 12014.

Wear, D. N., \& Bolstad, P. (1998). Land-use changes in southern Appalachian landscapes: spatial analysis and forecast evaluation. Ecosystems, 1(6), 575-594.

West Virginia Code (2011). Environmental Resources Natural Streams Preservation Act.Chapter 22. Article 13. §22-13-4.

West Virginia Farmland Protection: Counties. (2003). Retrieved September 4, 2014, from: http://www.wvfarmlandprotection.org/counties.cfm

Wilkinson, K. P. (1991). The community in rural America (No. 95). Greenwood Publishing Group.

Williams, D. R., \& Stewart, S. I. (1998). Sense of place: An elusive concept that is finding a home in ecosystem management. Journal of Forestry, 96(5), 18-23.

Williamson, S., Brunckhorst, D. J., \& Kelly, G. C. (2003). Reinventing the common: Crossboundary farming for a sustainable future. Federation Press.

Wondolleck, J. M., \& Yaffee, S. L. (2000). Making collaboration work: Lessons from innovation in natural resource managment. Island Press.

WV DOF.(2010).West Virginia Statewide Forest Resource Assessment. West Virginia Division of Forestry.http://www.wvforestry.com/DOF100Assessment_Revised_091310_Part 1.pd 
WV State Tax Department (WVSTD) (2013). (personal communication Kelly Hurley, Help Desk Analyst II, WV State Tax Department)

Yaffee, S. L. (1999). Three faces of ecosystem management. Conservation Biology, 13(4), 713-725.

Zedler, J. B. (2003). Wetlands at your service: reducing impacts of agriculture at the watershed scale. Frontiers in Ecology and the Environment, 1(2), 65-72.

Zhang, Y., Zhang, D., \& Schelhas, J. (2005). Small-scale non-industrial private forest ownership in the United States: rationale and implications for forest management. Silva Fennica, 39(3), 443. 


\title{
Appendices
}

\section{Appendix A. Pre-Survey Postcard}

\section{side one}

\section{Notice of Upcoming Survey}

\section{West Virginia Property Owners}

\author{
Dear WV Property Owner:
}

\begin{abstract}
A few days from now you will receive a survey designed to collect information about West Virginia's farmland and woodlands. This is part of a research project that is being conducted by West Virginia University. WVU's Institutional Review Board acknowledgement of this study is on file.
\end{abstract}

We are asking for your participation. Your insight can provide valuable information about farm and woodland owners and help to guide state and local agencies in important landscape level conservation efforts.

Please look for this questionnaire in your mailbox. It is with your generous help that this research can be successful. Thank you in advance for your participation.

Dave McGill

Professor/Extension Specialist (304) 293-5930; dmcgill@wvu.edu

W WestVirginiaUniversity.

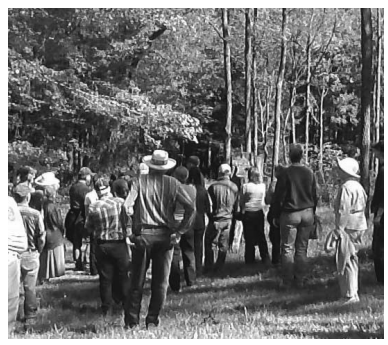

\section{side two}

\section{WestVirginiaUniversity.}

Dave McGill

West Virginia University

Division of Forestry \& Natural Resources

PO Box 6125

Morgantown, WV 26506

Return Service Requested

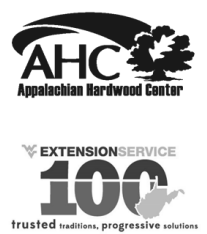

550183100002

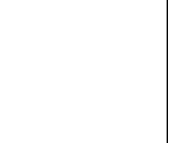




\title{
Appendix B. Cover Letter Initial Mailing
}

\author{
W. WestVirginiaUniversity. \\ Davis College of Agriculture, Forestry, and Design \\ Extension Service
}

January 7, 2015

Dear West Virginia Property Owner:

We are writing to ask for your help in a research project to learn more information about West Virginia's farmland and woodland owners. Please help us by taking a few minutes to fill out this survey.

We are sending this survey to private property owners in West Virginia. Your insight can provide valuable information about farmland and woodland owners' conservation activities and future management interests. Through this research we hope to improve outreach education programs for West Virginia landowners.

Please consider contributing your experience and knowledge to this research effort. Your participation in this survey is voluntary and you can quit any time without any penalty. You do not have to answer all of the questions, but any information you provide will contribute to the project's success. You must be over 18 years of age to participate. If you do not wish to participate, please let us know by returning the enclosed questionnaire, blank or with a note, in the prepaid envelope provided.

Information you provide is confidential; only summaries will be reported in which a single individual's answers cannot be identified. When you return your completed questionnaire, your name will be deleted from the mailing list and will not be connected to your answers in any way.

Acknowledgement of this study is on file with West Virginia University's Institutional Review Board.

If you have any further questions, please feel free to contact us at the phone numbers below. Thank you in advance for your participation. It is with your generous help that our research can be successful.

Sincerely,

Dr. Dave McGill, Principal Investigator Professor/Extension Specialist Forest Resources Management (304) 293-5930
Valerie Grant

Graduate Research Assistant

(681) 404-2341 


\title{
Appendix C. Cover Letter Second Mailing
}

\author{
W. WestVirginiaUniversity. \\ Davis College of Agriculture, Forestry, and Design \\ Extension Service
}

February 3, 2015

Dear West Virginia Property Owner:

Two weeks ago we mailed you a questionnaire that is part of a West Virginia University research project seeking information about your knowledge and experience as a West Virginia property owner. According to our records, you have not yet returned the survey.

We are writing again because your participation in this survey is important to get accurate results. Receiving your response is key to getting a representative view of the actions and attitudes of West Virginia property owners. Please consider contributing your experience and knowledge to this research effort.

Again, your participation in this survey is voluntary and you can quit any time without any penalty. You do not have to answer all of the questions, but any information you provide will contribute to the project's success. You must be over 18 years of age to participate. If you do not wish to participate, please let us know by returning the enclosed questionnaire, blank or with a note, in the prepaid envelope provided.

Information you provide is confidential; only summaries will be reported in which no individual's answers can be identified. When you return your completed questionnaire, your name will be deleted from the mailing list and will never be connected to your answers in any way. West Virginia University's Institutional Review Board acknowledgment of this study is on file.

If you have any further questions, please feel free to contact us at the phone numbers below. It is with your generous help that our research can be successful.

Sincerely,

Dr. Dave McGill, Principal Investigator Professor/Extension Specialist Forest Resources Management (304) 293-5930
Valerie Grant

Graduate Research Assistant

(681) 404-2341
Equal Opportunity/Affirmative Action Institution 
Appendix D. Questionnaire Extension Service WestVirginiaUniversity.

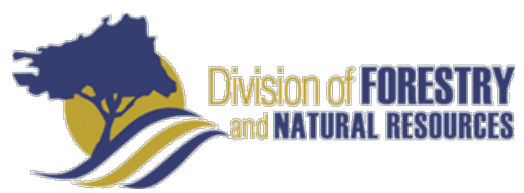

\section{West Virginia \\ Greenbrier River Valley \\ Farmland and Woodlands \\ Survey}

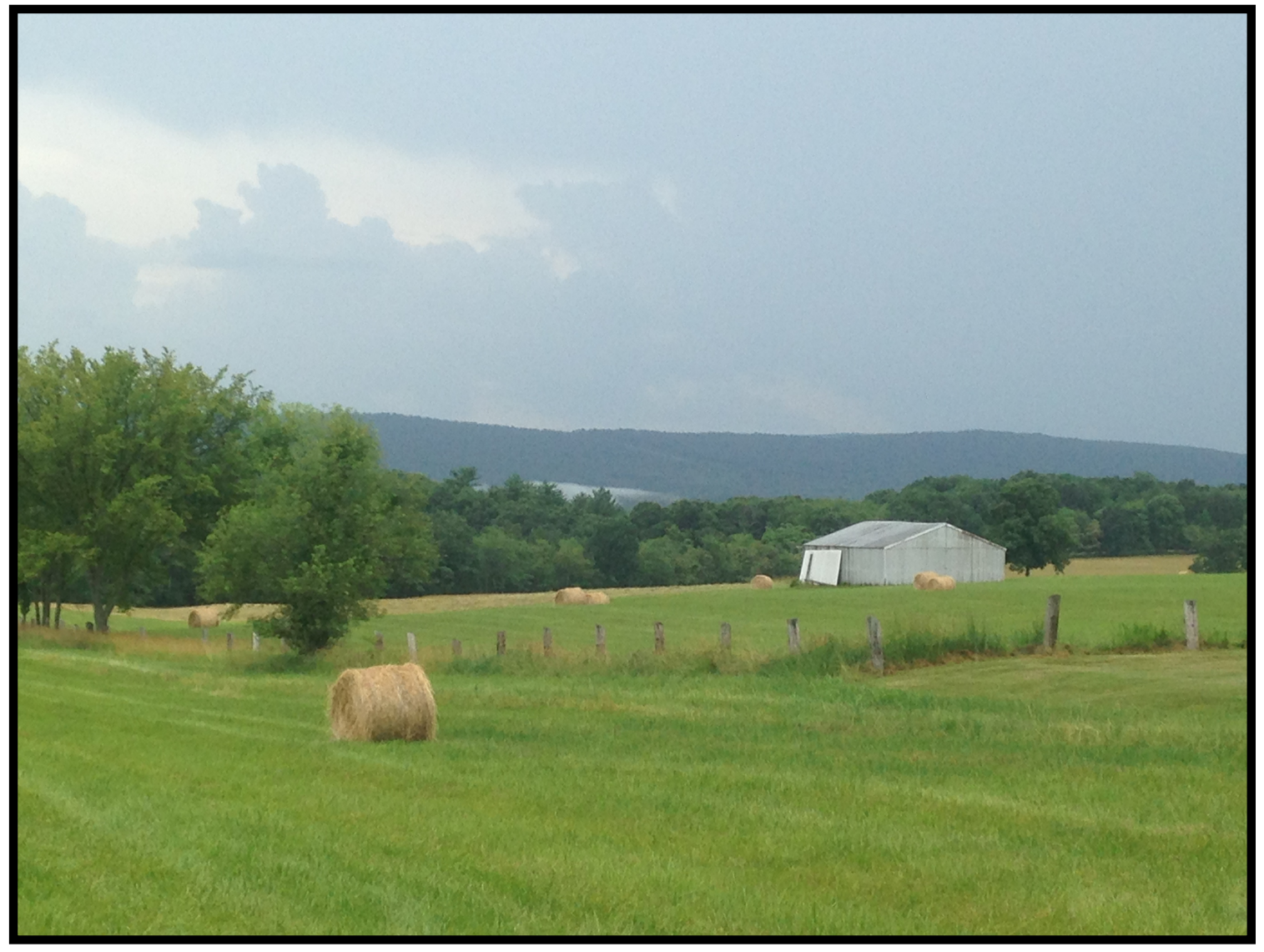

2015

If you have any questions please contact:

Dave McGill, Primary Investigator

Professor/Extension Specialist dmcgill@wvu.edu 304-293-5930
Valerie Grant

Graduate Research Assistant

vcgrant@mix.wvu.edu

681-404-2341 


\section{About This Survey}

The purpose of this survey is to explore the management preferences and motivations that West Virginia Farmland and Woodland Owners have for their properties and their local environment. Your insights will provide helpful information to guide state and local agencies, and private landowners in important landscape-level conservation efforts.

Definitions: For the purpose of this research we will use the following terms as defined by the West Virginia Tax Department:

Woodland is defined as any parcel of land that is covered by trees Agriculture land describes pasture or tillable land

Tillable land refers to acres of cleared land suitable for growing crops

Pastureland is considered land more suited for grazing livestock than for growing crops

Please fill the survey out even if you do not produce agriculture or forest products on your property. Your participation is voluntary and you have the right to refrain from answering any questions. Your answers will be kept confidential. Please ensure any changed answers are either clearly erased or crossed out.

Thank you for your assistance with this important research!

\begin{tabular}{|l} 
START HERE: \\
\begin{tabular}{|l|l|}
\hline & I do own woodland or agriculture property (please continue with the questionnaire). \\
\hline & I do not own woodland or agriculture property (please return blank questionnaire). \\
\hline & I prefer not to participate in this survey (please return blank questionnaire). \\
\hline & Please send me a summary of the results of this survey. \\
\hline
\end{tabular}
\end{tabular}

1. I reside in:

County, State

2. This research is primarily concerned with properties in the four counties listed below. Please fill in your ownership with respect to your property in West Virginia with agriculture lands (pasture or tillable) and/or woodlands (primarily tree cover). Leave blank the counties that do not apply to your ownership.

Property Owned in West Virginia Within Research Area

\begin{tabular}{|l|r|r|r|}
\hline \multicolumn{1}{|c|}{ County } & Agriculture (pasture/ tillable) & Woodland & Year Acquired \\
\hline Pocahontas & Acres & Acres & \\
\hline Greenbrier & Acres & Acres & \\
\hline Summers & Acres & Acres & \\
\hline Monroe & Acres & Acres & \\
\hline
\end{tabular}

3. Please indicate below if you own agriculture or woodland property in another WV county or another state (please check below).

I own other agriculture property

I own other woodland property

Does not apply

Please continue to next page. Page 1 
For the remainder of the questionnaire: Please think about your largest parcel in West Virginia.

4. My property is about miles from the town of

5. Do you reside on this property?

$\square$ yes $\square$ no

6. Do you lease any part of this property to someone?

Yes, leased for the purpose of: no

7. Is this property considered a farm? (Note: The US Dept of Agriculture defines a farm as property that produces $\$ 1,000$ or more of agricultural products per year)

$\square$ yes $\square$ no

8. How did you acquire this property in West Virginia? (check all that apply)

$\square$ purchased $\square$ inherited $\square$ received as gift $\square$ other (please specify)

9. Which category below best describes your ownership? (check only one)

\begin{tabular}{|l|l|l}
\hline & individual \\
family partnership & & $\begin{array}{l}\text { corporation or business partnership } \\
\text { joint, with spouse }\end{array}$
\end{tabular}$\quad \begin{aligned} & \text { multiple ownership (2 or more people) } \\
& \text { other (please specify) }\end{aligned}$

trust or estate

10. How is your property taxed ? (check all that apply)

$\square$ managed timberland $\square$ farmland $\square$ I don't know $\square$ other:

\section{Land Resources and Planning}

11. Have you ever contacted a professional forester about your property?

$\square$ yes $\square$ no

12. Have you ever contacted an agriculture professional about your property?

$\square$ yes $\square$ no

13. Do you currently have a written plan for your property? (check all that apply)

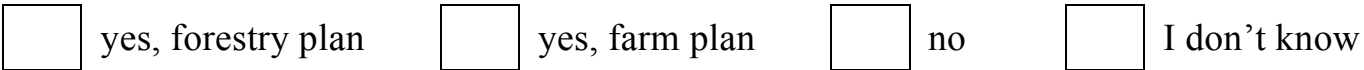

There are many federal and state incentives and cost share programs that have funds available for farm and woodland conservation activities (check all that apply).

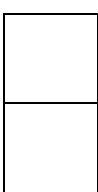

I have never heard of these funds

I would like more information about these funds.

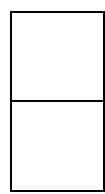

Yes, I have applied for funds but did not receive them

Yes, I have applied for and received these type of funds

101
Page 2 


\section{Cooperative Activities}

14. Please indicate your position about the following statements (check one).

a. Do you consider the ecological health of neighboring or nearby properties when making decisions concerning your land?

b. Have your neighbors or owners of nearby properties spoken to you about their management decisions?

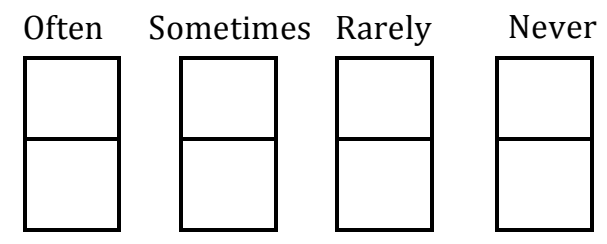

15. Please indicate your level of interest with the following cooperative activity statements (circle).

\begin{tabular}{|c|c|c|c|c|c|}
\hline & $\begin{array}{c}\text { Very } \\
\text { Interested }\end{array}$ & $\begin{array}{l}\text { Somewhat } \\
\text { Interested }\end{array}$ & Neutral & $\begin{array}{c}\text { Somewhat } \\
\text { Uninterested }\end{array}$ & $\begin{array}{c}\text { Very } \\
\text { Uninterested }\end{array}$ \\
\hline $\begin{array}{l}\text { In the future, I would be interested in working with } \\
\text { my neighbors to write a conservation easement } \\
\text { agreement to protect more than one ownership from } \\
\text { development. }\end{array}$ & 1 & 2 & 3 & 4 & 5 \\
\hline $\begin{array}{l}\text { In the future, I would be interested in asking my } \\
\text { neighbors to join a group to lease hunting and } \\
\text { recreation access to our shared properties. }\end{array}$ & 1 & 2 & 3 & 4 & 5 \\
\hline $\begin{array}{l}\text { In the future, I would be interested in talking with } \\
\text { my neighbors about managing wildlife habitat } \\
\text { together. }\end{array}$ & 1 & 2 & 3 & 4 & 5 \\
\hline
\end{tabular}

\section{Ideas About Land}

16. Please indicate your level of agreement with the following statements (circle).

\begin{tabular}{|c|c|c|c|c|c|}
\hline & $\begin{array}{l}\text { strongly } \\
\text { disagree }\end{array}$ & disagree & neutral & agree & $\begin{array}{l}\text { strongly } \\
\text { agree }\end{array}$ \\
\hline Land should be preserved for future generations & 1 & 2 & 3 & 4 & 5 \\
\hline Personal history and identity are closely tied to my/our land & 1 & 2 & 3 & 4 & 5 \\
\hline Agriculture is part of the historical character of my community & 1 & 2 & 3 & 4 & 5 \\
\hline I have a responsibility to conserve nature & 1 & 2 & 3 & 4 & 5 \\
\hline I manage land to maximize benefit to my community & 1 & 2 & 3 & 4 & 5 \\
\hline It is important to be a good steward & 1 & 2 & 3 & 4 & 5 \\
\hline My community is where I most belong & 1 & 2 & 3 & 4 & 5 \\
\hline I feel more myself on my property than anywhere & 1 & 2 & 3 & 4 & 5 \\
\hline I feel a spiritual connection to where I live & 1 & 2 & 3 & 4 & 5 \\
\hline Natural amenities should be preserved for future generations & 1 & 2 & 3 & 4 & 5 \\
\hline If the natural amenities changed I would not stay & 1 & 2 & 3 & 4 & 5 \\
\hline $\begin{array}{l}\text { Land in my community offers the natural amenities I am looking } \\
\text { for in a place to live. }\end{array}$ & 1 & 2 & 3 & 4 & 5 \\
\hline My family's livelihood depends on economic productivity of land & 1 & 2 & 3 & 4 & 5 \\
\hline My future livelihood depends on having flexible land use & 1 & 2 & 3 & 4 & 5 \\
\hline Financial well-being conflicts with plans for conservation & 1 & 2 & 3 & 4 & 5 \\
\hline $\begin{array}{l}\text { I am counting on the future value and productivity of my land to } \\
\text { support me in retirement. }\end{array}$ & 1 & 2 & 3 & 4 & 5 \\
\hline
\end{tabular}




\section{Present and Future Activities on Your Land}

18. Describe how your land activities may change in the future.

19. In the first column happening now, please describe if the following Infrastructure and Property Management activities have occurred on your property during the time you have owned the land. For the second column, future plans indicate the degree to which you might carry out these activities on your property in the next ten years (circle).

\begin{tabular}{|c|c|c|c|c|c|c|}
\hline \multirow[b]{2}{*}{ Infrastructure and Property Management } & \multicolumn{2}{|c|}{ Happening Now } & \multicolumn{4}{|c|}{ Future Plans } \\
\hline & & & increase & decrease & $\begin{array}{l}\text { stay the } \\
\text { same }\end{array}$ & not sure \\
\hline gardening & Yes & No & 1 & 2 & 3 & 4 \\
\hline building a home/cabin & Yes & No & 1 & 2 & 3 & 4 \\
\hline building a barn/shed or improving buildings & Yes & No & 1 & 2 & 3 & 4 \\
\hline $\begin{array}{l}\text { posting boundary to prevent trespassing/ fencing to } \\
\text { delineate property boundary }\end{array}$ & Yes & No & 1 & 2 & 3 & 4 \\
\hline fencing for livestock & Yes & No & 1 & 2 & 3 & 4 \\
\hline fencing to keep deer out & Yes & No & 1 & 2 & 3 & 4 \\
\hline building game blinds or tree stands & Yes & No & 1 & 2 & 3 & 4 \\
\hline removing invasive species & Yes & No & 1 & 2 & 3 & 4 \\
\hline $\begin{array}{l}\text { removing trees with storm or insect damage / cutting } \\
\text { trees that have fallen on roads or fences/clear brush }\end{array}$ & Yes & No & 1 & 2 & 3 & 4 \\
\hline pond maintenance or development & Yes & No & 1 & 2 & 3 & 4 \\
\hline stream restoration (planting vegetation, clearing debris) & Yes & No & 1 & 2 & 3 & 4 \\
\hline improving access to streams & Yes & No & 1 & 2 & 3 & 4 \\
\hline foot trail development/maintenance & Yes & No & 1 & 2 & 3 & 4 \\
\hline new access road development & Yes & No & 1 & 2 & 3 & 4 \\
\hline access road maintenance & Yes & No & 1 & 2 & 3 & 4 \\
\hline selling part of the woodland & Yes & No & 1 & 2 & 3 & 4 \\
\hline selling part of the agriculture lands & Yes & No & 1 & 2 & 3 & 4 \\
\hline selling all of the land & Yes & No & 1 & 2 & 3 & 4 \\
\hline transferring land ownership to family member & Yes & No & 1 & 2 & 3 & 4 \\
\hline transferring land to conservation easement & Yes & No & 1 & 2 & 3 & 4 \\
\hline leasing the land & Yes & No & 1 & 2 & 3 & 4 \\
\hline applying for cost-share funds (for example NRCS EQIP) & Yes & No & 1 & 2 & 3 & 4 \\
\hline
\end{tabular}


20. In the first column happening now, please describe if the following Agriculture and Forestry Production activities have occurred on your property, during the time you have owned the land. For the second column, future plans indicate the degree to which you might carry out these activities on your property in the next ten years (circle).

\begin{tabular}{|c|c|c|c|c|c|c|}
\hline \multirow[b]{2}{*}{ Agriculture and Forestry Production } & \multicolumn{2}{|c|}{ Happening Now } & \multicolumn{4}{|c|}{ Future Plans } \\
\hline & & & increase & decrease & $\begin{array}{l}\text { stay the } \\
\text { same }\end{array}$ & not sure \\
\hline grazing cattle & Yes & No & 1 & 2 & 3 & 4 \\
\hline raising livestock & Yes & No & 1 & 2 & 3 & 4 \\
\hline row cropping & Yes & No & 1 & 2 & 3 & 4 \\
\hline growing crops in a greenhouse/high tunnel & Yes & No & 1 & 2 & 3 & 4 \\
\hline fruit or vegetable production for sale & Yes & No & 1 & 2 & 3 & 4 \\
\hline orchard production & Yes & No & 1 & 2 & 3 & 4 \\
\hline harvesting hay & Yes & No & 1 & 2 & 3 & 4 \\
\hline fishing & Yes & No & 1 & 2 & 3 & 4 \\
\hline trapping or hunting wildlife & Yes & No & 1 & 2 & 3 & 4 \\
\hline wildlife watching (for example, bird watching) & Yes & No & 1 & 2 & 3 & 4 \\
\hline extracting natural gas or other minerals & Yes & No & 1 & 2 & 3 & 4 \\
\hline $\begin{array}{l}\text { harvesting medicinal herbs or gathering forest } \\
\text { mushrooms }\end{array}$ & Yes & No & 1 & 2 & 3 & 4 \\
\hline cutting trees for firewood & Yes & No & 1 & 2 & 3 & 4 \\
\hline harvesting timber/timbering & Yes & No & 1 & 2 & 3 & 4 \\
\hline
\end{tabular}

\section{Demographics}

Please answer the following questions about yourself (Your answers are strictly confidential).

21. What is your gender?

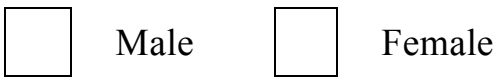

22. What is your age?

\begin{tabular}{|c|c|c|c|c|}
\hline $18-24$ & $35-44$ & $55-59$ & $65-74$ & 85 or greater \\
\hline $25-34$ & $45-54$ & 60 & & \\
\hline
\end{tabular}

23. What is your annual gross income

\begin{tabular}{|c|c|c|c|}
\hline$\$ 15,000-\$ 24,999$ & $\$ 35,000-\$ 49,999$ & $\$ 75,000$ - $\$ 99,999$ & $\$ 200,000$ or more \\
\hline$\$ 25,000-\$ 34,999$ & $\$ 50,000-\$ 74,999$ & $\$ 100,000-\$ 199,999$ & \\
\hline
\end{tabular}

24. What is the highest level of education you have completed?

\begin{tabular}{|l|l|l|l}
$\begin{array}{l}\text { less than high school } \\
\text { high school graduate }\end{array}$ & $\begin{array}{l}\text { some college, no degree } \\
\text { associates degree }\end{array}$
\end{tabular}$\quad \begin{aligned} & \text { bachelors degree } \\
& \text { graduate or professional degree }\end{aligned}$

\section{Thank You for participating in this survey!}

Please return the completed questiongqire in the postage-paid envelope. 


\section{Appendix E. Reminder Postcard}

\section{side one}

\section{Reminder About Important Survey W-West VirginiaUniversity}

Dear WV Property Owner:

Two weeks ago we mailed a survey designed to collect information about West Virginia farmland and woodland owners. This is part of a research project that is being conducted by West Virginia University. WVU's Institutional Review Board acknowledgement of this study is on file.

If you have already completed and returned the survey, please accept our sincere thanks. If not, please take a few minutes to do so today. Your insight can provide valuable information about West Virginia property owners and help to guide state and local agencies in important landscape level conservation efforts.

If you did not receive a survey or have misplaced it, please call me and I will mail another one immediately. Thank you in advance for your participation.

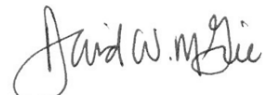

Dave McGill

Professor/Extension Specialist

(304) 293-5930; dmcgill@wvu.edu

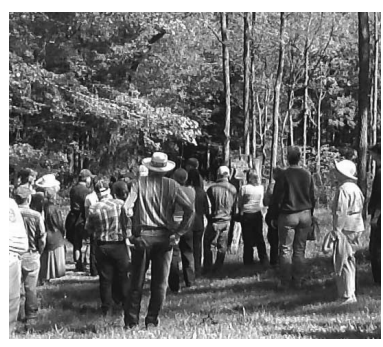

\section{side two}
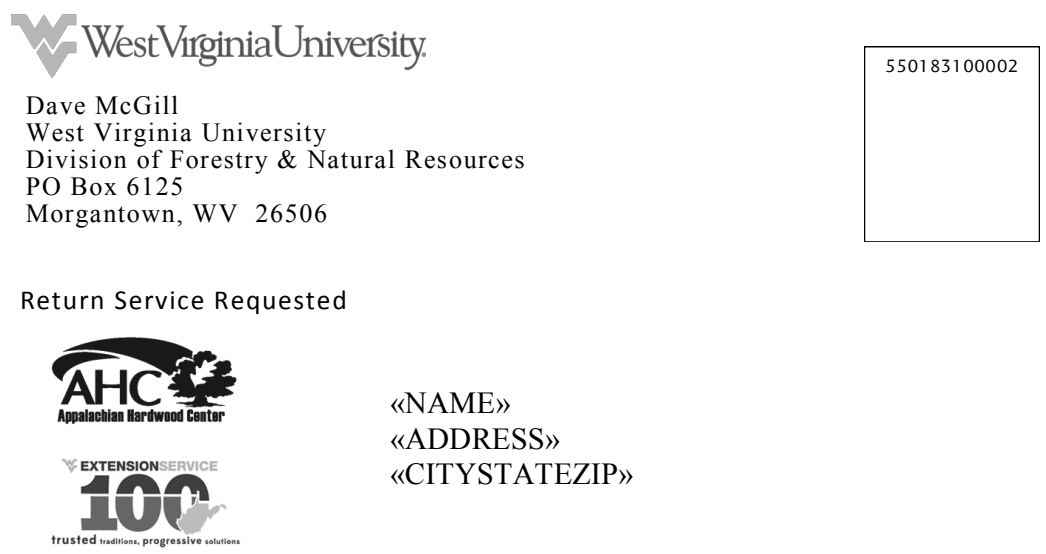